\title{
A MODERN INTEGRATED PARADIGM FOR INTERNATIONAL RESPONSIBILITY ARISING FROM VIOLATIONS OF ECONOMIC, SOCIAL, AND CULTURAL RIGHTS
}

\author{
Diane A. Desierto ${ }^{*}$ \\ Colin E. Gillespie ${ }^{\dagger}$
}

\begin{abstract}
From its entry into force in 1976 up to its present membership of 160 States Parties, the interpretation of the International Covenant on Economic, Social and Cultural Rights (hereafter, the Covenant) has always involved confronting normative and institutional complexities. Unlike the specific prohibitions contained in the International Covenant on Civil and Political Rights (ICCPR), Covenant norms purposely contemplate dynamic implementation over time, with the quality of treaty compliance expected to accommodate and adjust to States' governance capabilities, resource endowments, and fiscal contexts. Such interpretive variability, however, did not necessarily doom the Covenant to normative indeterminacy. Rather, as we show in Part I (A Normative Lattice: The Determinacy of Economic, Social, and Cultural Rights), the lattice-like normative system of the Covenant still enables a reasoned assessment of international responsibility and compliance by State and non-State actors with Covenant obligations. Covenant interpreters must first identify the legal social protection baseline applicable to the State (e.g. the 'minimum core content of Covenant obligations' that are jointly determined at the outset by each State Party with the Committee on Economic, Social, and Cultural Rights upon the State's accession to the Covenant), in conjunction with two overarching obligations flowing parallel with this baseline - the principle of nondiscrimination', which requires a State Party to guarantee non-discrimination in their implementation of Covenant rights; and the 'principle of non-retrogression', which commits a State Party to social protection conduct that will, at the very least, not fall below its pre-committed legal baseline of the 'minimum core' of Covenant rights. These two principles and the 'minimum core' baseline comprise the starting point for the periodic assessment of compliance with the Covenant. Beyond this point, Covenant interpreters have to assess the State's continuing obligation to 'progressively realize' Covenant rights as the State's fiscal, economic, and governance contexts and capabilities accordingly adapt and develop over time. We further note that the programmatic, evolutive, and transactional nature of economic, social and cultural rights inimitably involves a spectrum of actors - States as well as
\end{abstract}

\footnotetext{
Assistant Professor of Law, Co-Director of the ASEAN Law \& Integration Center, University of Hawaii William S. Richardson School of Law, Honolulu, USA, and Adjunct Fellow, East-West Center. JSD, LLM, Yale Law School.

+ C.V. Starr Lecturer-in-Law (2012-2013), Peking University School of Transnational Law, China; incoming Law Clerk (2013-2014), U.S. Court of Appeals 2nd Cir. N.Y.
}

Copyright $\odot$ the Author(s).

This work is licensed under a Creative Commons Attribution-NonCommercial-NoDerivs 3.0 License. 
non-State actors (such as international organizations). As we show in Part II (Expanding Universes: Covenant Interpreters and Violations by State and non-State Actors), international responsibility for Covenant violations could attach, not just for conduct of States and non-State actors that breach individual substantive obligations in Articles 6 to 15 of the Covenant, but also from breach of the overriding 'duty to cooperate' that was built into the telos and design of Covenant obligations. The duty to cooperate, as recognized throughout the General Comments issued by the Committee, is an obligation that has particular salience especially in times of economic emergencies or resource scarcities impairing States Parties' abilities to 'respect, protect, and fulfill' economic, social and cultural rights. As is axiomatic with the law of international responsibility, Covenant violations give rise to a corollary duty to make reparations. However, the ultimate form of relief granted would depend on the actual jurisdictional remit of the forum chosen to adjudicate the Covenant violation. In this respect, the proliferation of authoritative institutions that now interpret the Covenant (e.g. the Committee on Economic, Social and Cultural Rights; States Parties; international, regional, and national courts and tribunals; other specialized agencies of the United Nations) explains the diversity of forms of relief recognized as sufficient reparations for Covenant violations. In the Conclusion (Reframing International Responsibility for Covenant Violations), we point out the convergence of various dialectical achievements throughout nearly five decades since the entry into force of the Covenant: 1) the sustained quasi-legislative work of the Committee throughout its General Comments; 2) the continuing interpretive practices of national, regional, and international courts and tribunals in regard to economic, social, and cultural rights; 3 ) the broad participation and interpretive praxis of States, international organizations, and other nonState actors in the settled reportage procedures before the Committee; and 4) the recent adoption of empirical methodologies for assessing human rights compliance. These developments helped ripen a modern interpretive paradigm for the authoritative determination of international responsibility for Covenant violations.

In the field of treaty interpretation, the choice of a particular interpretive theory may simultaneously involve a choice in the wider forum of international politics. At the simplest level, the choice of one method of interpretation over another...may determine the result in a particular case. At the broader level, interpretive strategies may signal more far-reaching, non-legal choices and goals. ${ }^{1}$

1 D S Berry, 'Hyper-Interpretation: Promise or Peril?' (2008) 102 ASIL Proc 416, 416-20. 
[...] while there are always mechanisms for ruling out readings, their source is not the text but the presently recognized interpretive strategies for producing the text $[. . .]^{2}$

The Committee on Economic, Social and Cultural Rights [...] is a subsidiary organ that has the task of 'assisting' the [UN Economic and Social] Council in carrying out responsibilities vested by the Covenant not in the former but in the latter [...] in the longer term, the Committee would benefit from being accorded a steadily increasing degree of autonomy. ${ }^{3}$

\section{Introduction: Interpretive Gaps in the Assessment of State Responsibility for Covenant Violations}

There has not been much practical elucidation, whether from international tribunals or bodies, of an authoritative interpretive process when assessing State responsibility arising from violations of the International Covenant on Economic, Social and Cultural Rights (the Covenant or ICESCR). Indeed, the International Court of Justice has not yet had the opportunity to adjudicate allegations of Covenant breaches in an actual contentious case. Its single finding to date of a Covenant breach was in the 2004 Advisory Opinion on Legal Consequences of the Construction of a Wall in the Occupied Palestinian Territory (Wall Advisory Opinion), ${ }^{4}$ when the Court declared that the construction of the wall impede[s] the exercise by the persons concerned of the right to work, to health, to education, and to an adequate standard of living as proclaimed in the International Covenant on Economic, Social and Cultural Rights. ${ }^{5}$ In support of this conclusion, the Court cited information received from the Secretary-General of the United Nations; ${ }^{6}$ the UN Special Rapporteur of the Commission on Human Rights on the situation of human rights in the Palestinian territories

\footnotetext{
2 S Fish, Is There a Text in This Class? The Authority of Interpretive Communities (1980) 347.

3 P Alston \& B Simma, 'Current Development: First Session of the UN Committee on Economic, Social and Cultural Rights' (1987) 81 AJIL 747, 755-6.

${ }^{4}$ Legal Consequences of the Construction of a Wall in the Occupied Palestinian Territory, Advisory Opinion, ICJ Reports 2004 p 136.

${ }^{5}$ Ibid, para 134.

${ }^{6}$ Ibid, para 132.
} 
occupied by Israel since 1967; ${ }^{7}$ a Report of the Special Committee to Investigate Israeli Practices Affecting the Human Rights of the Palestinian People and Other Arabs of the Occupied Territories; ${ }^{8}$ and the Special Rapporteur on the Right to Food of the UN Commission on Human Rights. ${ }^{9}$ However, there is no indication in the Wall Advisory Opinion that the Court obtained and relied on information from Israel, nongovernmental organizations, or other institutions, experts, or persons to controvert and establish the factual bases behind its declaration of Israel's violation of the Covenant. The Court preferred to leave the matter of its interpretive methodology quite open for future development in actual contentious proceedings.

Even the Committee on Economic, Social and Cultural Rights (the Committee), the body composed of 18 independent experts specifically tasked with monitoring States Parties' implementation of the Covenant, ${ }^{10}$ has been reticent in issuing any definitive declarations of State violations of the Covenant. While the Committee has declared States Parties to have acted inconsistently with Covenant obligations (such as those on the right to housing, in the cases of the Dominican Republic, Panama, and the Philippines ${ }^{11}$ ), it has usually refrained from categorically declaring other State violations of the Covenant in most cases, a policy attributable to the limited mandate delegated to the Committee by the Economic and Social Council under Part IV of the Covenant, as much as to the Committee's own preferences for less confrontational language urging States to comply with Covenant obligations. ${ }^{12}$ Other than its explication of Covenant norms through the General Comments it has issued thus far, ${ }^{13}$ the Committee has not yet de-

7 Ibid.

8 Ibid.

9 Ibid.

10 The Economic and Social Council delegated its treaty monitoring authority under Part IV of the Covenant to the Committee. See Economic and Social Council, Review of the composition, organization, and administrative arrangements of the Sessional Working Group of Governmental Experts on the Implementation of the International Covenant on Economic, Social and Cultural Rights, UN Doc E/RES/1985/17, 28 May 1985.

${ }^{11}$ UN Committee on Economic, Social and Cultural Rights (CESCR or the Committee), Concluding Observations of the Committee on Economic, Social and Cultural Rights: Dominican Republic, UN Doc E/C.12/1994/15, 19 December 1994; CESCR Concluding observations of the Committee on Economic, Social and Cultural Rights: Panama, UN Doc E/C.12/1/Add.64, 24 September 2001; K Parlett, The Individual in the International Legal System: Continuity and Change in International Law (2011) 319.

${ }^{12}$ See S Leckie, 'The Committee on Economic, Social and Cultural Rights: Catalyst for Change in a System Needing Reform', in P Alston \& J Crawford (eds), The Future of UN Human Rights Treaty Monitoring (2000) 129-44.

${ }^{13}$ For the full text of the Committee's General Comments issued from 1989 to 2009, see <http://tbin- 
fined a predictable methodology for how it would conduct the legal and evidentiary assessment of international responsibility for breaches of the Covenant. ${ }^{14}$ However, with the entry into force of the Optional Protocol to the Covenant ${ }^{15}$ in May 2013 and the corresponding expansion of the Committee's competences to include procedures for individual and/or group communications, broad and extensive motu proprio fact-finding and inter-State communications, ${ }^{16}$ it is inevitable that in the near future the Committee will be impelled to more frequently and directly treat the question of international responsibility for Covenant violations.

This Article aims to contribute to the ongoing scrutiny of the processes and methods of interpretation involved in ascertaining international responsibility for Covenant violations. This will be done by focusing on the methodological techniques and forensic evidentiary practices of the Covenant's pluralist community of institutional interpreters (e.g. the Committee; international and national courts and tribunals; other UN specialized agencies and international organizations), and subsequently extrapolating features therefrom to describe a modern interpretive paradigm for determining international responsibility for Covenant violations. We note that, while the 1997 Maastricht Guidelines on Violations of Economic, Social and Cultural Rights (the Maastricht Guidelines) developed by the International Commission of Jurists have been recommended by the United Nations Commission on Human Rights to national human rights institutions dealing with Covenant violations, ${ }^{17}$ they remain non-binding due to their soft law

ternet.ohchr.org/_layouts/treatybodyexternal/TBSearch.aspx?Lang=en\&TreatyID=9\&DocTypeID $=11>$ [accessed 30 July 2013].

${ }^{14}$ We note that several Committee members were present in the experts' meetings convened for the purpose of adopting the Limburg Principles on the Implementation of the ICESCR ( $\mathrm{Limburg}$ Principles) (UN Commission on Human Rights, Note verbale dated 86/12/05 from the Permanent Mission of the Netherlands to the United Nations Office at Geneva addressed to the Centre for Human Rights ('Limburg Principles'), UN Doc E/CN.4/1987/17, 8 January 1987 in (1987) 9 HRQ 122). See: V Dankwa, C Flinterman \& S Leckie, 'Commentary to the Maastricht Guidelines on Violations of Economic, Social and Cultural Rights' (1998) 20 Human Rights Quarterly 705, 705-30. For a summary of the early features of Covenant violations identified in the Limburg principles, see S Leckie, 'Another Step towards Indivisibility: Identifying the Key Features of Violations of Economic, Social and Cultural Rights' (1998) 20 HRQ 81, 81-124.

${ }^{15}$ Full text of the Optional Protocol available at <http://www2.ohchr.org/english/law/docs/A.RES.63.117_en.pdf> [accessed 1 January 2014].

${ }^{16}$ For other work that focuses narrowly on the procedural and interpretive effects of new competences vested in the Committee as a result of the passage of the Optional Protocol, see D A Desierto \& C E Gillespie, 'Evolutive Interpretation and Subsequent Practice - Interpretive Communities and Processes in the Optional Protocol to the ICESCR' (2013) 73 ZaöRV 549.

17 Office of the UN High Commissioner for Human Rights, Economic, Social and Cultural Rights: Handbook for National Human Rights Institutions, UN Doc HR/P/PT/12, 2005, 45ff, 117-24 (Hand- 
status. ${ }^{18}$ Certainly neither the International Court of Justice or the Committee on Economic, Social and Cultural Rights appear to have explicitly referenced the Maastricht Guidelines in the rare instances where the Court or the Committee declared that a State violated the Covenant and was internationally responsible as such. ${ }^{19}$

We nonetheless accept the Maastricht Guidelines' conceptual articulation of Covenant violations as those that 'can occur through the direct action of States or other entities insufficiently regulated by States, ${ }^{20}$ as well as those that occur 'through the omission or failure of States to take necessary measures stemming from legal obligations. ${ }^{21}$ Our integrated paradigm diverges from the Maas-

book for National Human Rights Instruments). ICJ, Maastricht Guidelines on Violations of Economic, Social and Cultural Rights, 26 January 1997, <http://wwwl.umn.edu/humanrts/instree/Maastrichtguidelines_.html $>$ [accessed 30 July 2013].

18 International Commission on Human Rights Policy and International Commission on Jurists, Human Rights Standards: Learning from Experience, 2006, 15, <http://www.ichrp.org/files/reports/31/120b_report_en.pdf> [accessed 30 July 2013]. It has been proposed that both the 1987 Limburg Principles and the Maastricht Guidelines on Violations of Economic, Social and Cultural Rights could be regarded as 'subsidiary means' for the interpretation of the Covenant under Article 38(1)(d) of the Statute of the International Court of Justice (ICJ Statute). See M Ssenyonjo, 'Economic, Social and Cultural Rights: An Examination of State Obligations', in S Joseph \& A McBeth (eds), Research Handbook on International Human Rights Law (2010) 36, 41. One scholar cautions against over-reliance on the United Nations' 'positivist' approach to economic, social and cultural rights: W F Felice, 'The Viability of the United Nations Approach to Economic and Social Human Rights in a Globalized Economy' (1999) 75 International Affairs 563, 596 ('to move beyond merely denouncing violations, to actual implementation of a strategy to improve the working and living conditions of the most vulnerable sectors, must involve popular participation. The people whose economic and social rights have been violated should be a part of the implementation process.').

${ }^{19}$ We note that the Maastricht Guidelines' broad definitions of Covenant violations do not appear to have been reflected in the practice of international tribunals. A survey of supranational tribunals' adjudication of economic, social and cultural rights held that there was a 'fairly consistent pattern: a willingness to adjudicate failures of the obligation to respect, but virtually no tolerance for allegations of failures to protect or fulfill rights.' See D Marcus, 'The Normative Development of Socioeconomic Rights through Supranational Adjudication' (2006) 42 Stanford JIL 53, 88.

${ }^{20}$ Maastricht Guidelines, above n 17, para 14, subparagraphs (a)-(g). (Examples include: the formal removal or suspension of necessary legislation; denial of Covenant rights to particular individuals or groups; active support for third-party measures that are inconsistent with the Covenant; adoption of deliberately retrogressive measures that reduce the extent to which any Covenant right is guaranteed; calculated obstruction of, or halt to, the progressive realization of a right protected by the Covenant; as well as reduction or diversion of specific public expenditure resulting in non-enjoyment of Covenant rights without adequate measures to ensure minimum subsistence rights).

${ }^{21}$ Ibid, para 15, subparagraphs (a)-(j). Examples include failures to: take appropriate steps as 
tricht Guidelines only to the extent that we differentiate between evidentiary thresholds, modes of reparations and items of relief afforded by the kind of forum in which a claim of international responsibility for a Covenant violation is brought. ${ }^{22}$ While complexities do attend the interpretation of economic, social and cultural rights under the Covenant, they are not, in our view, so insurmountable as to render it impossible for the States burdened to devise pragmatic fiscal programs in the ordinary course of their economic decision-making, as well as to implement urgent policy responses and distributive welfare measures during economic crises and financial emergencies. ${ }^{23}$

The methodological question for interpreters of economic, social and cultural rights in the Covenant has always been more a matter of how to frame this particular treaty's evolving norms and their deeply contextual application to dynamic circumstances faced by individual States Parties. ${ }^{24}$ We submit that various critiques against the salience of the Covenant-such as the supposed indeterminacy

required under the Covenant; reform or repeal legislation which is manifestly inconsistent with Covenant obligations; enforce legislation or put into effect policies designed to implement the Covenant; regulate activities of individuals or groups so as to prevent them from violating Covenant rights; utilize maximum available resources towards full realization of the Covenant; monitor the realization of Covenant rights; remove obstacles to the immediate fulfillment of Covenant rights; implement without delay Covenant rights that must be provided immediately; meet a generally accepted international minimum standard of achievement, which is within the state's powers to meet; and take into account Covenant rights when entering into bilateral or multilateral agreements with other states, international organizations or multinational corporations.

${ }^{22}$ In contrast, the Maastricht Guidelines broadly prescribe that any state found responsible for violating the Covenant is required to 'establish mechanisms to correct such violations, including monitoring, investigation, prosecution, and remedies for victims': ibid, para 16. Victims of Covenant violations are deemed 'entitled to adequate reparation, which may take the form of restitution, compensation, rehabilitation and satisfaction or guarantees of non-repetition': ibid, para 23.

${ }^{23}$ In this, we concur with Christine Chinkin's characterization of the 'hardening process' for international economic, social and cultural rights, where the 'level of obligation' has been perceptibly raised as a result of institutional initiatives, as well as state-driven experiences: C Chinkin, 'Normative Development in the International Legal System', in D Shelton (ed), Commitment and Compliance: The Role of Non-Binding Norms in the International Legal System (2003) 21, 33. For a recent example of the applicability of the ICESCR to states' economic decisions during financial or economic crises, see D A. Desierto, 'Conflict of Treaties, Interpretation, and Decision-Making on Human Rights and Investment during Economic Crises' (2013) 1 Transnational Dispute Management (Special Issue on Aligning Human Rights with Investment Protection).

${ }^{24}$ On clarifying the normative content of Covenant rights, see P Alston, 'Out of the Abyss: The Challenges Confronting the New U.N. Committee on Economic, Social and Cultural Rights' (1987) 9 HRQ 332, 351-5; B Simma, 'Foreign Investment Arbitration: A Place for Human Rights?' (2011) 60 ICLQ 573, 573-7; P Alston \& B Simma, 'Second Session of the UN Committee on 
and aspirational quality of Covenant obligations; ${ }^{25}$ the alleged ineffectiveness of the enforcement and oversight mechanisms in the Covenant; ${ }^{26}$ or the purported jettisoning of free market ideologies through supposedly paternalistic Covenant obligations ${ }^{27}$ - could be better addressed by examining the interpretive, evidentiary, and normative practices of the plurality of the Covenant's actual interpretive communities over five decades since the entry into force of the Covenant. To this end, our integrated paradigm deals with two dimensions of justiciability for purposes of determining international responsibility for Covenant violationsfirst, the "normative justiciability'28 of Covenant violations, which refers to precision of Covenant rights as to give rise to the 'possibility of applying a right in a specific case by judicial or quasi-judicial bodies' ${ }^{29}$ and second, the institutional justiciability, ${ }^{30}$ or the ability, competence, or function of a tribunal or body to

Economic, Social and Cultural Rights' (1988) 82 AJIL 603, 605-8.

${ }^{25}$ See e.g. H Lewis, "New” Human Rights? US Ambivalence Toward the International Economic and Social Rights Framework', in C Soohoo, C Albisa \& M F Davis (eds), Bringing Human Rights Home: A History of Human Rights in the United States (2009) 100, 129; K Bourquain, Freshwater Access from a Human Rights Perspective: A Challenge to International Water and Human Rights Law (2008) 236; C Puta-Chekwe \& N Flood, 'From Division to Integration: Economic, Social and Cultural Rights as Basic Human Rights', in I Merali \& V Oosterveld (eds), Giving Meaning to Economic, Social, and Cultural Rights (2001) 39, 43; G Baruchello \& R L Johnstone, 'Rights and Value: Construing the International Covenant on Economic, Social and Cultural Rights as Civil Commons' (2011) 5 Studies in Social Justice 91, 93; M Dowell-Jones, Contextualising the International Covenant on Economic, Social and Cultural Rights: Assessing the Economic Deficit (2004) 34-37.

${ }^{26}$ See e.g. L Camp Keith, 'Human Rights Instruments', in P Cane \& H M. Kritzer (eds), The Oxford Handbook of Empirical Legal Research (2010) 353, 359 ('The ICESCR, with its limited commitment to "take steps...to the maximum of its available resources" is arguably the weakest treaty in terms of commitment and monitoring'); W Osiatyński, Human Rights and Their Limits (2009) 127-8; W M Cole, 'Strong Walk and Cheap Talk: The Effect of the International Covenant on Economic, Social and Cultural Rights on Policies and Practices' (2013) 92 Social Forces 165.

${ }^{27}$ On the history behind the United States' rejection of the ICESCR under the Reagan Administration, see D J. Whelan, 'The United States and economic and social rights: past, present....and future?' (University of Denver Graduate School of International Studies, Working Paper No 26, 28 February 2005), <http://www.du.edu/korbel/hrhw/workingpapers/2005/26-whelan2005.pdf $>$ [accessed 30 July 2013].

${ }^{28}$ Aharon Barak distinguishes between 'normative justiciability' (whether there are legal criteria for determining a given dispute), and 'institutional justiciability' (whether it is appropriate for the institution seised of a dispute to adjudicate the question brought before it): A Barak, The Judge in a Democracy (2009) 178-85.

${ }^{29}$ K Roepstorff, 'Economic, Social and Cultural Rights and the Question of Justiciability: International Legal Protection of the Right to Food', in K Hoffmann-Holland (ed), Ethics and Human Rights in a Globalized World: An Interdisciplinary and International Approach (2009) 301, 311.

${ }^{30}$ Barak, above n 28. 
adjudicate or assess violations of Covenant rights. ${ }^{31}$

Part I (A Normative Lattice: The Determinacy of Economic, Social, and Cultural Rights), addresses the issue of normative justiciability using a latticelike analytical starting point for treaty interpreters. States Parties are required to observe a 'minimum core' of Covenant obligations-a legal social protection baseline determined jointly with the Committee on Economic, Social, and Cultural Rights shortly after the State's accession to the Covenant. ${ }^{32}$ Two further overarching obligations flow in parallel with this legal baseline - the 'principle of non-discrimination, ${ }^{33}$ which requires a State Party to guarantee nondiscrimination in their implementation of Covenant rights; and the 'principle of non-retrogression, ${ }^{34}$ which commits a State Party to social protection con-

${ }^{31}$ K D Beiter, The Protection of the Right to Education by International Law (2006) 79 ('Justiciability involves two questions: firstly, should the adjudicator act and, secondly, can the adjudicator act? [...] Both dimensions of justiciability may be addressed by drafting precise, narrow standards').

32 CESCR, General Comment No 3: The Nature of States Parties Obligations (Art. 2, Para. 1 of the Covenant), UN Doc E/1991/23, 14 December 1990, para 10 (General Comment No 3) ('On the basis of the extensive experience gained by the Committee, as well as by the body that preceded it, over a period of more than a decade of examining States parties' reports the Committee is of the view that a minimum core obligation to ensure the satisfaction of, at the very least, minimum essential levels of each of the rights is incumbent upon every State party [...] If the Covenant were to be read in such a way as not to establish such a minimum core obligation, it would be largely deprived of its raison d'être. By the same token, it must be noted that any assessment as to whether a State has discharged its minimum core obligation must also take account of resource constraints applying within the country concerned. Article 2(1) obligates each State party to take the necessary steps the maximum of its available resources. In order for a State party to be able to attribute its failure to meet at least its minimum core obligations to a lack of available resources it must demonstrate that every effort has been made to use all resources that are at its disposition in an effort to satisfy, as a matter of priority, those minimum obligations').

${ }^{33}$ CESCR, General Comment No 20: Non-discrimination in economic, social and cultural rights (art. 2, para. 2 of the International Covenant on Economic, Social and Cultural Rights), UN Doc E/C.12/GC/20, 2 July 2009, para 7 (General Comment No 20) ('Non-discrimination is an immediate and cross-cutting obligation in the Covenant. Article 2, paragraph 2, requires States parties to guarantee non-discrimination in the exercise of each of the economic, social and cultural rights enshrined in the Covenant and can only be applied in conjunction with these rights.')

${ }^{34}$ H Jenkins, Background Paper Submitted to the Committee on Economic, Social and Cultural Rights: Global Economic Governance and National Policy Autonomy in the Pursuit of Economic, Social and Cultural Rights, UN Doc E/C.12/2001/6, 7 May 2001, para 8 ('In particular, member States that have signed and ratified the International Covenant on Economic, Social and Cultural Rights have legal obligations to "achieve progressively" the full rights set out in the Covenant, and must also afford "international assistance and cooperation" for this purpose. In other words, Governments must demonstrate, individually and collectively, that they are taking concrete steps toward realization of these rights. A major duty deriving from these obligations is 
duct that will, at the very least, not fall below its pre-committed legal baseline of the 'minimum core' of Covenant rights. These two principles and the 'minimum core' baseline together comprise the normative lattice from which the Committee undertakes its periodic assessment of a State's compliance with the Covenant. Beyond this point, the Committee builds its further assessment of how a State discharges its separate and continuing obligation to 'progressively realize ${ }^{, 35}$ Covenant rights as the State's fiscal, economic, and governance contexts and capabilities accordingly adapt and develop over time.

We approach the 'institutional justiciability' of Covenant violations from a pluralist prism recognizing that the Committee does not have exclusive or primary interpretive competence over the Covenant. ${ }^{36}$ The programmatic, evolutive, and transactional nature of economic, social and cultural rights compliance inimitably involves participation of actors across a broad spectrum-from States Parties to the Covenant to non-State actors such as international organizations. ${ }^{37}$ Accordingly, Part II (Expanding Universes: Covenant Interpreters and Violations by State and non-State Actors) discusses how international responsibility for Covenant violations could attach not just to conduct of States and non-State actors in breach of individual substantive obligations in Articles 6 to 15 of the Covenant, but also to breach of the overarching 'duty to cooperate' as part of the telos and design of Covenant obligations. ${ }^{38}$ The duty to cooperate, as

the "principle of non-retrogression"-meaning that State parties must not take retrogressive measures (through law or policy) that would jeopardize existing achievements, except in the limited circumstances specifically provided for in the relevant human rights instrument'). For a more detailed explication of the principle, see C Gillespie, Non-retrogression \& Civil and Political Rights (under submission, manuscript on file with author).

${ }^{35}$ Covenant, Art 2(1). See CESCR, General Comment No 3, above n 32, para 9.

${ }^{36}$ We concede that the Committee's interpretations of the Covenant (either through its practice of issuing General Comments, Concluding Observations in regard to the Article 16/17 periodic state reporting process, and other unilateral statements), while often persuasive, are not always determinative, binding, or completely authoritative upon other international or domestic agencies, organizations, tribunals or courts seeking to interpret and apply Covenant norms. The Committee has even been criticized for 'not always [being] rigorous in its concluding observations': M Langford \& J A King, 'Committee on Economic, Social and Cultural Rights', in M Langford (ed), Social Rights Jurisprudence: Emerging Trends in International and Comparative Law (2008) 477, 493. For other examples criticizing instances of the Committee's 'neglect' of the unitary system of interpretation in Article 31 of the Vienna Convention on the Law of Treaties, see K Mechlem, 'Treaty Bodies and the Interpretation of Human Rights' (2009) 42 Vanderbilt JTL 905, 930-44.

${ }^{37}$ See F Coomans, 'Application of the International Covenant on Economic, Social and Cultural Rights in the Framework of International Organisations' (2007) 11 Max Planck YUNL 359.

${ }^{38}$ See M den Heijer \& R Lawson, 'Extraterritorial Human Rights and the Concept of "Jurisdiction”, 
recognized throughout the General Comments issued by the Committee, ${ }^{39}$ is an obligation that has particular salience in times of economic emergencies or resource shortages that may impair States Parties' abilities to 'respect, protect and fulfill' economic, social and cultural rights. We further show that while Covenant violations axiomatically give rise to a corollary duty to make reparations, the ultimate form of relief granted would depend on the actual jurisdictional remit of the

in M Langford, W Vandenhole, M Scheinin, \& W Van Genugten (eds), Global Justice, State Duties: The Extraterritorial Scope of Economic, Social and Cultural Rights in International Law (2012) 153, 183 (stressing that the Covenant 'does differ from civil and political human rights treaties in that it contains an inherent international outlook [and] imposes the general obligation upon States to engage in international assistance and cooperation to realize the rights recognized in the Covenant').

${ }^{39}$ CESCR, General Comment No 3, above n 32, paras 8, 12; CESCR, General Comment No 2: International Technical Assistance Measures (Art 22 of the Covenant), UN Doc E/1990/23, 2 February 1990, para. 9 (General Comment No 2); CESCR, General Comment No 4: The Right to Adequate Housing (Art 11(1) of the Covenant), UN Doc E/1992/23, 13 December 1991, paras 8-11, 13, 18; CESCR, General Comment No 5: Persons with Disabilities, UN Doc E/1995/22, 9 December 1994, para 12; CESCR, General Comment No 7: The Right to Adequate Housing (Art 11(1): Forced Evictions), UN Doc E/1998/22, 20 May 1997, paras 4, 6; CESCR, General Comment No 8: The Relationship between Economic Sanctions and Respect for Economic, Social and Cultural Rights, UN Doc E/C.12/1997/8, 12 December 1997, paras 7, 10; CESCR, General Comment No 9: The Domestic Application of the Covenant, UN Doc E/C.12/1998/24, 3 December 1998, para 10 (General Comment No 9); CESCR, General Comment No 10: The Role of National Human Rights Institutions in the Protection of Economic, Social and Cultural Rights, UN Doc 1 E/C.12/1998/25, 10 December 1998, para 3; CESCR, General Comment No 11: Plans of Action for Primary Education (Art 14 of the Covenant), UN Doc E/1992/23, 10 May 1999, para 9; CESCR, General Comment No 12: The Right to Adequate Food (Art 11 of the Covenant), UN Doc E/C.12/1999/5, 12 May 1999, paras 6, 15, 17, 28; CESCR, General Comment No 13: The Right to Education (Art 13 of the Covenant), UN Doc E/C.12/1999/10, 8 December 1999, paras 6, 57; CESCR, General Comment No 14: The Right to the Highest Attainable Standard of Health (Art 12 of the Covenant), UN Doc E/C.12/2000/4, 11 August 2000, paras 11, 12, 28, 43, 47 (General Comment No 14); CESCR, General Comment No 15: The Right to Water (Arts 11 and 12 of the Covenant), UN Doc E/C.12/2002/11, 20 January 2003, paras 10, 37, 41 (General Comment No 15); CESCR, General Comment No 16: The Equal Right of Men and Women to the Enjoyment of All Economic, Social and Cultural Rights (Art 3 of the Covenant), UN Doc E/C.12/2005/4, 11 August 2005, paras 20, 42 (General Comment No 16); CESCR, General Comment No 17: The Right of Everyone to Benefit from the Protection of Moral and Material Interests Resulting from Any Scientific, Literary or Artistic Production of Which He or She is the Author (Art 15, para 1(c) of the Covenant), UN Doc E/C.12/GC/17, 12 January 2006, paras 39, 41 (General Comment No 17); CESCR, General Comment No 18: The Right to Work (Art 6 of the Covenant), UN Doc E/C.12/GC/18, 6 February 2006, paras 30, 32 (General Comment No 18); CESCR, General Comment No 19: The Right to Social Security (Art 9 of the Covenant), UN Doc E/C.12/GC/19, 4 February 2008, paras 3, 50, 55 (General Comment No 19); CESCR, General Comment No 21: Right of Everyone to Take Part in Cultural Life (Art 15, para. 1(a) of the Covenant on Economic, Social and Cultural Rights), UN Doc E/C.12/GC/21, 21 December 2009, paras 23, 59 (General Comment No 21). 
forum chosen to adjudicate the Covenant violation. The diversity of forms of relief granted against Covenant violations may be explained from the proliferation of authoritative institutions that now interpret the Covenant-the Committee; States Parties; international, regional and national courts and tribunals; other specialized agencies of the UN, among others. However, as we have discussed elsewhere ${ }^{40}$ we also anticipate that three new Committee procedures now operative under the Optional Protocol to the Covenant would aid in streamlining and harmonizing Covenant interpretation by enabling the consolidation of information $^{41}$ on states' subsequent practices in relation to the Covenant within the meaning of Article 31(3)(b) of the Vienna Convention on the Law of Treaties $(\operatorname{VCLT}) .^{42}$

In the Conclusion (Reframing International Responsibility for Covenant Violations), we point out the convergence of various dialectical achievements throughout nearly five decades since the entry into force of the Covenant: 1) the sustained quasi-legislative work of the Committee throughout its General Comments; 2) the continuing interpretive practices of national, regional, and international courts and tribunals in regard to economic, social, and cultural rights; 3 ) the broad participation and interpretive praxis of States, international organizations, and other non-State actors in the settled reportage procedures before the Committee; and 4) the recent adoption of empirical methodologies for assessing human rights compliance. These developments, we submit, help

\footnotetext{
${ }^{40}$ Desierto \& Gillespie, above $\mathrm{n} 16$.

${ }^{41}$ For other works expressing our respective concerns about the legitimacy and accuracy of information-gathering techniques in human rights treaties in general, as well as in relation to the Covenant, see P Alston \& C Gillespie, 'Global Human Rights Monitoring, New Technologies, and the Politics of Information' (2012) 23 EJIL 1089; B Simma \& D A Desierto, 'Bridging the Public Interest Divide: Committee Assistance for Investor-Host State Compliance with the ICESCR', in D Hanschel, S Graf Kielmansegg, U Kischel, C Koenig, R A Lorz (eds), Mensch und Recht: Festschrift für Eibe Riedel zum 70. Geburtstag (Essays in Honour of Eibe Riedel) (2013) 1-15, reprinted in (2013) 10 Transnational Dispute Management, <http://www.transnational-dispute-management.com/article.asp?key=1931> [accessed 30 July 2013].

${ }^{42}$ See Covenant, Arts 16, 17 (on mandatory state reporting processes required in the Covenant); Vienna Convention on the Law of Treaties, 23 May 1969, 1155 UNTS 331, Art 31(3)(b) ('There shall be taken into account, together with the context [...] any subsequent practice in the application of the treaty which establishes the agreement of the parties regarding its interpretation'). For a synthesized description of the Committee's work on normative interpretation of the Covenant and the Committee's relationship with other specialized agencies of the United Nations, see K Arambulo, 'The International Covenant on Economic, Social and Cultural Rights and the Committee on Economic, Social and Cultural Rights', in P Van der Auweraert, T De Pelsmaeker, J Sarkin \& J Vande Lanotte (eds), Social, Economic and Cultural Rights: An Appraisal of Current European and International Developments (2002) 57.
} 
ripen today's modern integrated paradigm for the authoritative determination of international responsibility for Covenant violations.

\section{A Normative Lattice: The Determinacy of Economic, Social, and Cultural Rights}

Claims about the alleged indeterminacy of economic, social, and cultural rights under the Covenant are often, at their core, manifestations of 'semantic skepticism', or 'the claim that there are no facts that constitute or determine a sentence's meaning, so that language is indeterminate at the most basic level: there are no objective facts that make it the case that language means one thing rather than another. ${ }^{43}$ The indeterminacy supposedly arises from the fact that Covenant rights 'remained deliberately abstract,' ${ }^{44}$ such that it would only be through 'understanding the resources and pressures of interpretation [that one] helps to contain the indeterminacy of economic and social rights. ${ }^{34}$

We do not share the assumption above that Covenant rights are troublingly or inherently indeterminate; rather, we adhere to the view that Covenant obligations, similar to other human rights norms (such as civil and political rights ${ }^{46}$ whose meaning and content achieved settled definition after repeated application, are (and have in fact shown themselves) amenable to rules of treaty interpretation. ${ }^{47}$ While meaning must certainly be elicited from open-textured Covenant rights such as 'the right to the highest attainable standard of health'; ${ }^{48}$ 'the right of everyone to education'; ${ }^{49}$ or the 'right of everyone to an adequate

\footnotetext{
${ }^{43}$ J L Coleman \& B Leiter, 'Determinacy, Objectivity, and Authority' (1993) 142 U Pa LR 549, 568.

${ }^{44}$ K G Young, Constituting Economic and Social Rights (2012) 28.

${ }^{45}$ Ibid, 31.

${ }^{46}$ See C Mbazira, Litigating Socio-Economic Rights in South Africa: A Choice between Corrective and Distributive Justice (2009) 26 ('where the vagueness of civil and political rights has partly been cleared up through many years of adjudication; socio-economic rights have not had a similar advantage. This is one of the reasons why a complaints procedure to ICESCR has been adopted. To deny the justiciability of socio-economic rights is to limit the opportunities of elaboration of the obligations they engender').

${ }^{47}$ See P Alston \& G Quinn, 'The Nature and Scope of States Parties' Obligations under the International Covenant on Economic, Social and Cultural Rights' (1987) 9 HRQ 156; United Kingdom House of Lords and House of Commons Joint Committee on Human Rights, The International Covenant on Economic, Social and Cultural Rights: Twenty-first Report of Session 2003-04 (2004) 24.

${ }^{48}$ Covenant, Art 12(1).

${ }^{49}$ Covenant, Art 13(1).
} 
standard of living for himself and his family, including adequate food, clothing and housing, and to the continuous improvement of living conditions, ${ }^{50}$ we likewise note that these rights have not lain dormant in nearly five decades of the existence and application of the Covenant by its States Parties with the Committee in clarifying the normative content of the Covenant. ${ }^{51}$ As the Committee pointed out in its General Comment No 9 in 1998, many Covenant provisions are capable of immediate implementation, such as 'articles 3, 7(a)(i), 8, 10(3), 13(2)(a), 13(3), 13(4), and 15(3) [...] there is no Covenant right which could not, in the great majority of systems, be considered to possess at least some significant justiciable dimensions. 52

Accordingly, the assessment of State responsibility for Covenant violations should begin with describing the normative starting point at which one evaluates the State's compliance with its continuing typology ${ }^{53}$ of obligations to 'respect,', 'protect', 55 and 'fulfill' 56 economic, social and cultural rights. We use the metaphor of a 'normative' lattice to make this starting point readily identifiable for treaty interpreters. This normative lattice would be composed of three elements that are mutually reinforcing and cross-cutting in the treaty interpreter's assessment of State responsibility: first, the 'minimum core' of Covenant obligations, the content of which is determined jointly by the State Party with the Committee shortly after the former's accession to the Covenant, such core operating as the guaranteed baseline of social protection regardless of the State Party's economic circumstances; second, the 'principle of non-discrimination', which prohibits de facto and de jure discriminatory treatment in the State Party's application of measures to comply with its Covenant obligations; and third, the

\footnotetext{
${ }^{50}$ Covenant, Art 11(1).

51 See M M Sepúlveda, The Nature of the Obligations under the International Covenant on Economic, Social and Cultural Rights (2003) 132-3 (detailing the role of the repeated application of Covenant rights in the development of their normative content by the Committee with states parties).

52 CESCR, General Comment No 9, above n 39, para 10.

${ }^{53}$ See A Eide, The Right to Adequate Food as a Human Right, UN Doc E/CN.4/Sub.2/1987/23, 7 July 1987 (where the tripartite typology was first proposed in the context of the Covenant).

54 The obligation to respect the Covenant 'requires States to abstain from performing, sponsoring or tolerating any practice, policy, or legal measure violating the integrity of individuals or infringing upon their freedom to use those material or other resources available to them in ways they find most appropriate to satisfy economic, social and cultural rights': Office of the UN High Commissioner for Human Rights, above n 17, 15.

55 The obligation to protect Covenant rights 'requires the State and its agents to prevent the violation of any individual's rights by any other individual or non-State actor': ibid, 17.

${ }^{56}$ The obligation to fulfill Covenant rights 'requires positive measures by the State when other measures have not succeeded in ensuring the full realization of these rights': ibid, 18.
} 
'principle of non-retrogression', which restrains the State Party from unjustifiably implementing lower levels of social protection under the Covenant than either the minimum core that the State Party has committed to, or the current standard of social protection treatment that the State Party has already observed. As a doctrinal and descriptive matter essential to assessing State responsibility for Covenant violations, we discuss each of these three elements seriatim:

\subsection{Minimum Core Obligations}

The minimum core content of Covenant rights is meant to 'establish $[$ a minimum quantitative and qualitative threshold enjoyment of each [ESC] right that should be guaranteed to everyone in all circumstance as a matter of top priority [...] [it] is linked to vital interests of individuals that are often connected to their survival. ${ }^{57}$ States must observe, regardless of resource or material constraints-a 'minimum core obligation to ensure the satisfaction of, at the very least, minimum essential levels of each of the rights. ${ }^{58}$ A State Party can only justify its failure to meet this minimum core content due to a lack of available resources if it shows that 'every effort has been made to use all resources that are at its disposition in an effort to satisfy, as a matter of priority, those minimum obligations. ${ }^{59}$ Observance of Covenant's minimum core obligation is required even in times of 'economic recession', where 'the vulnerable members of society can and indeed must be protected by the adoption of relatively low-cost targeted programmes' ${ }^{60}$

Together with the Committee, the State Party to the Covenant participates in the contextual determination of the 'minimum core' content of Covenant obligations applicable to it, through the submission of the State Party's initial report required under Articles 16 and 17 of the Covenant. The Committee's initial assessment of the particular 'minimum core' content or baseline applicable to a given State Party then takes into consideration the State's resource capacities, population needs, scientific and technological advancement, among others. ${ }^{61}$ The

\footnotetext{
${ }^{57}$ A Müller, The Relationship Between Economic, Social and Cultural Rights and International Humanitarian Law: An Analysis of Health-Related issues in Non-International Armed Conflicts (2013) 75.

${ }^{58}$ CESCR, General Comment No 3, above n 32, para 10.

${ }^{59}$ Ibid, para 10.

${ }^{60}$ Ibid, para 12.

${ }^{61}$ See P Alston, above n 24, 332-81 (discussing at 351-353 how the Committee's mandate includes identification of the minimum core content of Covenant obligations). This process of identification, as evidenced by the Committee's varying practices across reporting processes, has not been immune from criticism: see M Langford \& J A King, 'Committee on Economic, Social and Cultural Rights', in M Langford (ed), Social Rights Jurisprudence: Emerging Trends in
} 
assessment is a broad-based information-gathering process, one that is intended to elicit the essential levels of a Covenant right, 'without which a right loses its substantive significance as a human right. ${ }^{\prime 62}$ The process of identifying a State Party's minimum core obligations under the Covenant emulates proportionality analysis. ${ }^{63}$ Following this paradigm, the Committee has been able to define and identify the criteria for determining the minimum core content of the right to food, ${ }^{64}$ the right to health, ${ }^{65}$ the right to social security, ${ }^{66}$ the right to water, ${ }^{67}$ among others. This methodology has parallels, with some differences, with those postulated by domestic constitutional courts, ${ }^{68}$ as well as with those enshrined in regional human rights systems. ${ }^{69}$

A final counterfactual militating against claims of indeterminacy of Covenant rights is the growing trend towards the empirical verification of States' compli-

International and Comparative Law (2008) 477, 492-5.

${ }^{62}$ Sepúlveda, above n 51, 366.

${ }^{63}$ See A Barak, Proportionality: Constitutional Rights and Their Limitations (2012) 202-10 (on proportionality and international and national human rights law); 422-34 (on proportionality and positive constitutional rights).

${ }^{64}$ CESCR, General Comment No 12, above n 39, para 17. See also R Künnemann, 'The Right to Adequate Food: Violations Related to its Minimum Core Content', in A Chapman \& S Russell (eds), Core Obligations: Building a Framework for Economic, Social and Cultural Rights (2002) 161.

${ }^{65}$ CESCR, General Comment No 14, above n 39, para 43. See also A R Chapman, 'Core Obligations Related to the Right to Health', in A Chapman \& S Russell (eds), Core Obligations: Building a Framework for Economic, Social and Cultural Rights (2002) 185.

${ }^{66}$ CESCR, General Comment No 19, above n 39, para 59. See also L Lamarche, 'The Right to Social Security in the International Covenant on Economic, Social and Cultural Rights', in A Chapman \& S Russell (eds), Core Obligations: Building a Framework for Economic, Social and Cultural Rights (2002) 87.

${ }^{67}$ CESCR, General Comment No 15, above n 39, para 37.

${ }^{68} \mathrm{~J}$ Chowdhury, 'Judicial Adherence to a Minimum Core Approach to Socio-Economic Rights - A Comparative Perspective' (Cornell Law School Graduate Paper No 27, 2009), citing Constitutional Court of Columbia decision, C-251/97; Constitutional Court of Columbia decision, SU-225-98; Paschim Banga Khet Mazdoor Samity $v$ State of West Bengal (1996) AIR SC 2426; Government of Republic of South Africa v Irene Grootboom and Petitioners 2001 (1) SA 46 (CC) (South Africa); Minister of Health v Treatment Action Campaign (No 2) 2002 (5) SA 721 (CC) (South Africa). On the reasonableness review and minimum core approach of the South African Constitutional Court, see S Liebenberg, 'Socio-Economic Rights: Revisiting the Reasonableness Review/Minimum Core Debate', in S Woolman \& M Bishop (eds) Constitutional Conversations (2008) 305.

${ }^{69}$ T Melish, Protecting Economic, Social and Cultural Rights in the Inter-American Human Rights System: A Manual on Presenting Claims (2002) 170-1; African Commission on Human and Peoples' Rights, Principles and Guidelines on the Implementation of Economic, Social and Cultural Rights in the African Charter on Human and People's Rights (2010) <http://www.escr-net.org/docs/i/1599552> [accessed 30 July 2013]. 
ance with Covenant rights. ${ }^{70}$ There are now various quantitative models and empirical methods for measuring the minimum core content of Covenant rights for particular States, factoring in resource constraints, governmental capabilities, and population needs of each State on a case-by-case basis. ${ }^{71}$ In 2012, the United Nations Office of the High Commissioner for Human Rights itself issued its consolidated volume, Human Rights Indicators: A Guide to Measurement and Implementation, ${ }^{72}$ which established a 'structure-process-outcome' framework ${ }^{73}$ of illustrative indicators to measure State compliance with Covenant rights such as the right to the enjoyment of the highest attainable standard of physical and mental health, the right to adequate food, the right to adequate housing, the right to education, the right to social security, the right to work, and the right to nondiscrimination and equality. ${ }^{74}$

\subsection{Principle of Non-Discrimination}

Non-discrimination appears both as a general cross-cutting obligation in the Covenant, ${ }^{75}$ as well as a specific obligation textualised within certain Covenant

\footnotetext{
${ }^{70}$ On the general trend of measurability of human rights compliance, see T Landman, 'Measuring Human Rights: Principle, Practice, and Policy' (2004) 26 HRQ 906.

${ }^{71}$ See G S McGraw, 'Defining and Defending the Right to Water and Its Minimum Core: Legal Construction and the Role of National Jurisprudence' (2011) 8 Loy U Chi ILR 127; S Kalantry, J E Getgen \& S A Koh, 'Enhancing Enforcement of Economic, Social, and Cultural Rights Using Indicators: A Focus on the Right to Education in the ICESCR' (2010) 32 HRQ 253; E Anderson, 'Using Quantitative Methods to Monitor Government Obligations in Terms of the Rights to Health and Education' (Center for Economic and Social Rights Working Paper, November 2008), <http://www.cesr.org/downloads/Quantitative\%20Methods\%20for\%20Measuring\%20ESCR.pdf> [accessed 30 July 2013]; E Felner, 'A New Frontier in Economic and Social Rights Advocacy? Turning Quantitative Data into a Tool for Human Rights Accountability' (2008) 9 Sur-International Journal on Human Rights 109. On auditing national government policies in light of the ICESCR, see methodology developed in R Balakrishnan \& D Elson, 'Auditing Economic Policy in the Light of Obligations on Economic and Social Rights' (2008) 5 Essex Human Rights Review 1.

${ }^{72}$ UN Office of the High Commissioner for Human Rights, Human Rights Indicators: A Guide to Measurement and Implementation, UN Doc HR/PUB/12/5, 2012. <http://www.ohchr.org/Documents/Publications/Human_rights_indicators_en.pdf> [accessed 30 July 2013].

${ }^{73}$ UN Office of the High Commissioner for Human Rights, Report on Indicators for Monitoring Compliance with International Human Rights Instruments, UN Doc HRI/MC/2006/7, 11 May 2006, <http://daccess-ods.un.org/TMP/9211648.70262146.html> [accessed 30 July 2013].

${ }^{74} \mathrm{Ibid}$ (see Annexes to the Article).

${ }^{75}$ Covenant, Art 2(2).
} 
rights. $^{76}$ Prior to its 2009 General Comment No 20 on the principle of non-discrimination, ${ }^{77}$ the Committee had examined the application of this principle in States Parties' Covenant obligations on housing, food, education, health, water, authors' rights, and social security. ${ }^{78}$ The Committee defines discrimination as

\begin{abstract}
'[... any distinction, exclusion, restriction or preference or other differential treatment that is directly or indirectly based on the prohibited grounds of discrimination and which has the intention or effect of nullifying or impairing the recognition, enjoyment or exercise, on an equal footing, of Covenant rights. Discrimination also includes incitement to discriminate and harassment. ${ }^{, 79}$
\end{abstract}

The Committee further distinguishes direct discrimination (an individual treated less favourably from another person in a similar situation for a reason related to a prohibited ground), from indirect discrimination (facially neutral laws, policies, or practices which have a disproportionate impact on the exercise of Covenant rights). ${ }^{80}$ Prohibited grounds of discrimination include: group membership, race, sex, language, religion, political and other opinions, national or social origin, property, birth, disability, age, nationality, marital and family status, health status, place of residence, and economic and social situation. ${ }^{81}$ While generally a state that fails to abide by the principle of non-discrimination is internationally responsible and in turn, obligated to stop the discriminatory action and compensate any victims for this violation, ${ }^{82}$ the Committee has confined the scope of remedies for breaching this principle merely to reminding States Parties to the Covenant that their national legislation and domestic institutions must investigate, provide access, and/or adjudicate harms caused by discrimination in economic, social and cultural rights. ${ }^{83}$ The Committee's

\footnotetext{
${ }^{76}$ Covenant, Art 3 (on equality in the enjoyment of Covenant rights); Art 7 (on equal remuneration for work of equal value); Art 13 (on compulsory and free primary education).

77 CESCR, General Comment No 20, above n 33, para 37.

${ }^{78}$ Ibid, para 6, citing CESCR, General Comment No 4; General Comment No 7; General Comment No 12; General Comment No 13; General Comment No 14; General Comment No 15; General Comment No 17; General Comment No 18; and General Comment No 19, above n 39.

${ }^{79}$ Ibid, para 7.

${ }^{80}$ Ibid, para 10.

${ }^{81}$ Ibid, paras 16-35.

${ }^{82}$ C F Doebbler, The Principle of Non-Discrimination in International Law (2007) 12.

${ }^{83}$ CESCR, General Comment No 20, above n 33, para 40.
} 
articulation of the principle of non-discrimination is silent on the consequences for the state responsibility for violating or failing to comply with this principle while discharging Covenant obligations-it is not altogether clear if a state's failure to comply with the principle of non-discrimination would constitute a separate breach independently giving rise to international responsibility, or alternatively, would merely be contextually considered when determining the gravity of the state's breach of another Covenant right. To this extent, the influence of this principle on the assessment of state responsibility for Covenant violations appears quite limited.

\subsection{Principle of Non-Retrogression}

The principle of non-retrogression has played an important role in articulating the content of economic, social, and cultural rights since the ratification and entry into force of Covenant. ${ }^{84}$ At its core, the principle of non-retrogression serves as an important means to evaluate whether or not states are fulfilling their obligations to 'progressively ensure' the rights protected by the Covenant. ${ }^{85}$ Put simply, if a state has taken measures which act to enhance the fulfillment of a particular economic, social, or cultural right protected under the Covenant, then the state cannot ratchet down protection of that right absent compelling circumstances.

The principle of non-retrogression derives, in the first instance, from the nature of the obligations imposed on states that have ratified the Covenant. Prior to articulating the specific rights covered by the Covenant, article 2 defines the nature of the obligations that bind states with respect to all of the rights articulated. Thus article 2(2) imposes on states the obligation to 'guarantee that the rights enunciated in the present Covenant will be exercised without discrimination. ${ }^{86}$ Article 2(3) allows '[d] eveloping countries [...] [to] determine

\footnotetext{
${ }^{84}$ See CESCR, General Comment No 3, above n 32. General Comment No 3 is the origin of the principle of non-retrogression.

${ }^{85}$ Covenant, Art 2(1) ('Each State Party to the present Covenant undertakes to take steps, individually and through international assistance and co-operation, especially economic and technical, to the maximum of its available resources, with a view to achieving progressively, the full realization of the rights recognized in the present Covenant by all appropriate means, including particularly the adoption of legislative measures.')

${ }^{86}$ Covenant, Art 2(2). This obligation has immediate effect. See CESCR, General Comment No 20, para. 7. See also S Ratjen and M Satija, 'Realising Economic, Social and Cultural Rights for All' in E Riedel, G Giacca and C Golay (eds), Economic Social and Cultural Rights: Contemporary Issues and Challenges (2014).
} 
to what extent they would guarantee the economic rights [...] to non-nationals. ${ }^{, 87}$ Article 2(1) imposes on States a different kind of obligation:

Each State Party to the present Covenant undertakes to take steps, individually and through international assistance and co-operation, especially economic and technical, to the maximum of its available resources, with a view to achieving progressively the full realization of the rights recognized in the present Covenant by all appropriate means, including particularly the adoption of legislative means. ${ }^{88}$

That states must take steps to 'achieve progressively' the rights in the Covenant arguably distinguishes the nature of the obligations in the ICESCR from the other major human rights instruments, in particular the ICCPR. ${ }^{89}$ Article 2(2) of the ICCPR, by way of contrast, does not include the language on progressive realization, but rather imposes on states the obligation 'to take the necessary steps [...] to adopt such laws or other measures as may be necessary to give effect to the rights recognized in the present Covenant. ${ }^{90}$ Article 2(1) obligates states to 'undertake to respect and to ensure' the rights protected under the ICCPR. ${ }^{91}$ The Committee ${ }^{92}$ took on the responsibility of

\footnotetext{
${ }^{87}$ Covenant, Art 2(3).

${ }^{88}$ Covenant, Art 2(1). The formulation might generously be called awkward, especially when compared to that of the International Covenant on Civil and Political Rights, 16 December 1966, 999 UNTS 171 (ICCPR). Compare ICESCR, Art 2(1) and ICCPR, Art 2(2) ('Each State Party to the present Covenant undertakes to take the necessary steps [...] to adopt such laws [...] as may be necessary'); see also ICCPR, Art 2(1). The question of what exactly it means to 'undertake to take steps [...] with a view to achieving progressively the full realization of rights' (emphasis added) is put to one side here, as it seems that the literature and jurisprudence seems to assume that the obligation is in fact to 'undertake to take steps [...] to progressively achieve the full realization of rights' (emphasis added).

${ }^{89}$ See also Convention on the Elimination of All Forms of Discrimination Against Women, 3 September 1981, 1249 UNTS 13, Art 2 (CEDAW) ('States Parties [...] agree to pursue by all appropriate means and without delay a policy of eliminating discrimination against women'); Convention on the Elimination of All Forms of Racial Discrimination, 7 March 1966, 666 UNTS 195, Art 2(1) (CERD) (same formulation in the context of racial discrimination).

${ }^{90}$ ICCPR, Art 2(2). This obligation is in addition to the obligations with respect to nondiscrimination in the Covenant, which are identical in the ICCPR, and the right to ensure an effective remed (ICCPR, Art 2(3)).

${ }^{91}$ ICCPR, Art 2(1). The fact of the differing nature of these obligations has, of course, been extensively commented on. See, e.g., A Rosga and M Satterthwaite, "The Trust in Indicators: Measuring Human Rights' (2009) 27 Berkeley JIL 253, 269 (noting that the distinction between the two types of obligations has been 'much-analyzed' and collecting sources).

${ }^{92}$ The precise role of treaty monitoring committees and a full examination of the value of general comments will not be given full consideration here. The value of general comments has been
} 
articulating the nature of state party obligations in General Comment No $3,^{93}$ issued in 1990. General Comment No 3 first notes that Article 2 'must be seen as having a dynamic relationship with all of the other provisions of the Covenant." This is so, it asserts, because '[i]t describes the nature of the general legal obligations undertaken by States parties. ${ }^{95}$ The Comment proceeds by articulating two obligations in the Covenant which are not susceptible to temporal analysis, but which states are obligated to undertake immediately, namely the non-discrimination elements of the Covenant ${ }^{96}$ and the obligation to 'take steps' to ensure that the rights in the covenant are fulfilled, which, the Committee notes, is 'not qualified or limited by other considerations." 97

After a discussion of the means by which state parties might fulfill their obligations under the Covenant, be they legislative of judicial, or in certain cases administrative, ${ }^{98}$ the Comment turns to the task of defining the meaning of the obligation to 'achiev[e] progressively' the rights guaranteed by the Covenant. The section is worth quoting at some length.

\section{The concept of progressive realization constitutes a recognition of}

\footnotetext{
described as ranging from 'authoritative interpretations of the relevant treaty norms, through...a de facto equivalent of advisory opinions which are to be treated with seriousness but not more, to highly critical approaches which classify them as broad, unsystematic, statements which are not always well founded'. P Alston, 'The Historical Origins of the Concept of "General Comments" in Human Rights Law', in H J Steiner, P Alston \& R Goodman (eds), International Human Rights in Context: Law, Politics, Morals ( $3^{\text {rd }}$ edn, 2008) 873, 874. Determining the value of general comments, or indeed taking a position on the value of general comments along the axis described above, is not necessary for present purposes for two reasons. The first is that this work chiefly tries to assess the meaning of the principle of non-retrogression across different treaty bodies. One can assume that a general comment is either binding, or persuasive, or evaluate whether it is well or poorly reasoned, and come to the conclusion that the value of the comment might be imported or exported across treaty bodies. Second, the question of whether the content of a general comment is authoritative or not should not have any bearing on whether it is persuasive or useful in a different context. To the extent that the principle of non-retrogression might be useful in the context of civil or political rights, one need not establish whether it is an authoritative interpretation of the 'progressively ensure' language of the ICESCR. The value of Committee comments might be open to more criticism, however, on the grounds that the Committee was not even envisioned by the Covenant itself, but was an ECOSOC creation, which makes it unique among the treaty-monitoring bodies.

${ }^{93}$ CESCR, General Comment No 3, above n 32.

${ }^{94}$ Ibid, para 1.

${ }^{97}$ Ibid, para 2.

${ }^{98}$ Ibid, paras 3-8.
}

95 Ibid.

96 Ibid. 
the fact that full realization of all economic, social and cultural rights will generally not be able to be achieved in a short period of time. In this sense the obligation differs significantly from that contained in article 2 of the ICCPR which embodies an immediate obligation to respect and ensure all of the relevant rights. Nevertheless, the fact that realization over time, or in other words progressively, is foreseen under the Covenant should not be misinterpreted as depriving the obligation of all meaningful content. It is on the one hand a necessary flexibility device [...] On the other hand, the phrase must be read in the light of the overall objective, indeed the raison d'etre of the Covenant which is to establish clear obligations for States parties in respect of the full realization of the rights in question. It thus imposes an obligation to move as expeditiously and effectively as possible towards that goal. Moreover, any deliberately retrogressive measures in that regard would require the most careful consideration and would need to be fully justified by reference to the totality of the rights provided for in the Covenant and in the context of the full use of the maximum available resources. ${ }^{99}$

Subsequent to this articulation of the non-retrogression principle, the Committee suggests that states parties are under an obligation to ensure a 'minimum core' of, inter alia, foodstuffs, health care, and housing, ${ }^{100}$ that is, particular rights that are guaranteed under the Covenant. ${ }^{101}$

\footnotetext{
${ }^{99}$ Ibid, para 9 (emphasis added).

${ }^{100}$ Ibid, para 10.

${ }^{101}$ Covenant, Arts 11(1)-(2), 12. The concept of the 'minimum core' is one that seems to have eclipsed in importance that of the principle of non-retrogression, at least in terms of the academic literature on economic social and cultural rights. See e.g., S Narula, "The Right to Food: Holding Global Actors Accountable under International Law' (2006) 44 Col JTL 691 (arguing that the minimum core of the right to food may have passed to the status of customary international law); K G Young, 'The Minimum Core of Economic and Social Rights: a Concept in Search of Content' (2008) 33 Yale JIL 113 (advocating greater use of indicators and benchmarks in the definition of the minimum core); see generally A R Chapman \& S Russell, 'Introduction', in A Chapman \& S Russell (eds), Core Obligations: Building a Framework for Economic, Social and Cultural Rights (3rd edn, 2002) 3 ('To contribute to the intellectual development of economic, social, and cultural rights [...] authors were asked to [...] sketch out the basis for the right [...] identify its minimum core content; and [...] describe several common violations of the right'); but see Rosga \& Satterthwaite, above $\mathrm{n} 92,306$ (noting that both non-retrogression and the concept of the minimum core work to clarify the nature of states' obligations with respect to economic social and cultural rights). The concepts of the minimum core and of the principle of non-retrogression share a common
} 
The non-retrogression principle thus, at its first articulation, has at least two important features. The first feature is that it requires an analysis of 'deliberation.' This deliberation is into the nature of any action that a state party takes which would arguably have implications for rights provided for in the Covenant. Incidentally retrogressive measures are arguably not accounted for when taking stock of party obligations under the treaty. The reason for this seems straightforward: the Comment is concerned with, above all, clarifying the nature of state obligations under the Covenant. In this respect, the Comment addresses itself to state decision makers considering not only what steps they must begin taking to fulfill their obligations, but also seeks to make these decision makers aware that actions that they may take, acts of commission in later general comment formulations, ${ }^{102}$ may bring states into a breach of their obligations as well.

A second feature of the principle of non-retrogression, especially relevant for the purposes of this argument, is that it suggests that acts of commission undertaken by States Parties that may bring them into breach of their treaty obligations must be analyzed by reference to all of the rights protected under the Covenant. The justification for expanding this frame seems to be a concern that gains made in the area of one area, health for example, are not to be made at the expense of other areas, for example water. What is particularly important here is that at its genesis the principle of non-retrogression is explicitly formulated in the context of obligations under the ICESR, which are in some sense opposed to the nature of obligations under the ICCPR. It is enough at this point to point out that the logic of analyzing retrogressive measures with respect to other ESCRs would also seem to imply that states should be obligated to analyze retrogressive measures in the area of all rights protected under both Covenants, rather than only the ICESCR, assuming that states are parties to both Covenants. There is no principled reason to believe otherwise, as it is axiomatic that all rights are interdependent and mutually reinforcing. ${ }^{103}$ Rights to health and water also have

\footnotetext{
heritage, of course. To the extent that one has been pursued at the expense of the other, the arguments set forth here attempt to remedy this balance.

${ }^{102}$ See e.g. above $\mathrm{n} 37$.

${ }^{103}$ See e.g., UN Commission on Human Rights, Question of the realization in all countries of the economic, social and cultural rights contained in the Universal Declaration of Human Rights and in the International Covenant on Economic, Social and Cultural Rights, and study of special problems which the developing countries face in their efforts to achieve these human rights, UN Doc E/CN.4/RES2001/30, 20 April 2001, para 4(d) (reaffirming the universality, indivisibility, interdependence and interrelatedness of all human rights and fundamental freedoms').
} 
a bearing on the right to not be arbitrarily deprived of one's life, for example. ${ }^{104}$ That the principle of non-retrogression may have been unnecessarily provincial at its first articulation does not, however, rob it of its force. Rather, it only speaks to the necessity of examining its scope in more detail.

The history of the application of the principle of non-retrogression in the general comments of the CESCR has roughly two stages. In the first stage, the principle is put into the background, as the Committee takes up other matters in its comments. The second, far more important stage for the purposes of this argument, is a process of institutionalizing the principle of non-retrogression, in which the committee gives it a wide scope of application, and fills out its jurisprudential value. Throughout this process the Committee has also been engaged in making particular recommendations, and voicing particular concerns, to state parties regarding their implementation of Covenant obligations, an engagement that often manifests itself in the concluding remarks offered by the Committee to state parties at the conclusion of those countries periodic reports, though has manifested itself in other ways as well. This process has also added greater depth to the principle.

Beginning with General Comment No 14, on the right to health, issued in $2000,{ }^{105}$ the principle of non-retrogression has become a recurring element of CESCR general comments. The initial reformulation and redeployment of the principle of non-retrogression in the context of a particular right protected under the Covenant in General Comment No 14 reads as follows.

As with all other rights in the Covenant, there is a strong presumption that retrogressive measures taken in relation to the right to health are not permissible. If any deliberately retrogressive measures are taken, the state party has the burden of proving that they have been introduced after the most careful consideration of all alternatives and that they are duly justified by reference to the totality of rights provided for in the Covenant in the context of the full use of the state parties maximum available resources. ${ }^{106}$

This exact same formulation has been deployed in subsequent general

\footnotetext{
${ }^{104}$ ICCPR, Art 6; see also Human Rights Committee, CCPR General Comment No 6: The Right to Life, UN Doc HRI/GEN/1/Rev.1, 30 April 1982 (HRC General Comment No 6) (noting that the interpretation of the rights protected under article 6 were unnecessarily circumscribed early in the application of the treaty, but that the treaty might also impose obligations on states to combat high rates of infant mortality or epidemics).

${ }^{105}$ CESCR, General Comment No 14, above n 39.

${ }^{106}$ Ibid, para 32.
} 
comments on the right to water, ${ }^{107}$ the right to enjoy the benefits of scientific progress, ${ }^{108}$ the right to work, ${ }^{109}$ and the right to social security, ${ }^{110}$ the only modification being the definition of the right at issue in the given general comment. ${ }^{111}$

Two elements of the formulation common to the vast number of general comments deploying the principle of non-retrogression are worth commenting on. The first is the introduction of the consideration of alternative measures into the analysis of the Committee. If the initial formulation of the principle of nonretrogression spoke in terms of a state-of-mind requirement, by focusing on $d e-$ liberately retrogressive measures, the principle of non-retrogression has, in subsequent years, developed to employ a proportionality analysis as well. This is so to the extent that it requires states to consider alternatives to retrogressive measures and choose the alternative that will least restrict enjoyment of the substantive rights provided for by the Covenant. A second element of the enhanced principle of non-retrogression is the introduction of legal presumptions into the analysis. While the initial formulation of the principle of non-retrogression spoke of the need for states to 'fully justif[y]' deliberately retrogressive measures, the more recent formulations of the CESCR arguably go further. While previously it might have been argued that states would need to justify retrogression only when a challenger to a state policy discharged a burden to prove that a state action was retrogressive, either the Committee, for example, or alternatively a rights-bearer,

${ }^{107}$ CESCR, General Comment No 15, above n 39, para 19.

${ }^{108}$ CESCR, General Comment No 17, above n 39, para 27 ('there is a strong presumption that retrogressive measures taken in relation to the right to the protection of the moral and material interest of authors are not permissible').

${ }^{109}$ CESCR, General Comment No 18, above n 39, para 21.

${ }^{110}$ CESCR, General Comment No 19, above n 39, para 42.

${ }^{111}$ General comments relating to discrimination are the exception to the way the principle of non-retrogression has been formulated more recently. Thus, in General Comment No 16, on the equal rights of men and women, the Committee opines that ' $t$ ] he adoption and undertaking of any retrogressive measures that affect the equal right of men and women to the enjoyment of all the rights set forth in the Covenant constitutes a violation of article 3' (CESCR, General Comment No 16, above n 39, para 42). A similar formulation appears in General Comment No 21, on the right of everyone to take place in cultural life. CESCR, General Comment No 21, above n 39, para 65 ('Any deliberately retrogressive measures in relation to the right to take part in cultural life would require the most careful consideration and need to be fully justified by reference to the totality of the rights provided for in the Covenant and in the context of the full use of the maximum available resources'). The only exception to the unanimous references to the principle of non-retrogression in the Committee's General Comments since 2000 is General Comment No 20, also on non-discrimination obligations under the Covenant (CESCR, General Comment No 20, above n 33). 
the principle of non-retrogression now imposes a burden of persuasion on states to prove that a retrogressive measure was in some sense necessary.

\subsection{Synthesizing the Normative Lattice}

Using the three elements of the foregoing normative lattice for the treaty interpreter's starting point, the process of assessing whether a state has violated a Covenant obligation can thus proceed to the examination of how the state ultimately complied with its fundamental obligation to 'progressively realize' Covenant rights under Article 2(1), in relation to the specific Covenant right or rights at issue. This minimum social protection baseline is the 'absolute international minimum' applicable at all times, ${ }^{112}$ beyond which a state party is obligated to respect, protect, and fulfill Covenant rights only through reasonably expected economic measures and policies applicable during normal business cycles. ${ }^{113}$ Notably, the higher standard of Covenant protection beyond the minimum social protection baseline would not automatically apply to a state party crippled by severe economic crises or fiscal emergencies. ${ }^{114}$ The assessment of a

${ }^{112}$ M Ssenyonjo, Economic, Social and Cultural Rights in International Law (2009) 66-7.

${ }^{113}$ See B Stark, 'At Last? Ratification of the Economic Covenant as a Congressional-Executive Agreement' (2011) 20 Trans L \& Contemp Probs 107, 141 ('First, there are many contexts in which economic rights are plainly justiciable. If such rights are assured in a discriminatory manner, for example, courts can and have ordered relief. The CESCR has identified several rights that require immediate implementation and are thus capable of judicial determination. These rights include, for example, Article 3's assurance of equal rights for men and women and Article 7's assurance of equal pay for work of equal value. Second, even where the issue is not discrimination, a judicial determination that the state is or is not meeting its obligations certainly seems within a court's competence. If the state is not meeting its obligations, the appropriate legislature or regulatory agency can determine exactly how it should do so. Matthew Craven notes that while it was argued during the drafting of the Covenant that "it would be impossible for a supervisory body to decide whether or not a State is acting in conformity with its obligations under the Covenant," this view has largely been rejected. Craven concludes, accordingly, that "there is, in fact, a justiciable core to every human right," a conclusion that the recent entry into force of the Optional Protocol confirms').

${ }^{114}$ The Committee clarified: 'Where the available resources are demonstrably inadequate, the obligation remains for a State party to ensure the widest possible enjoyment of economic, social and cultural rights under the prevailing circumstances....even in times of severe resource constraints, States parties must protect the most disadvantaged and marginalized members or groups of society by adopting relatively low-cost targeted programmes. The undertaking by a State party to use the "maximum" of its available resources [...] entitles it to receive resources offered by the international community [it] refers to both the resources existing within the State as well as those available from the international community through international cooperation and assistance.' See CESCR, An Evaluation of the Obligation to Take Steps to the 'Maximum 
state party's potential responsibility for Covenant violations would have to take place in a case-to-case dialogic basis between the Committee and the state party involved. It would be for the Committee to determine if the state party's lower level of Covenant protection is justifiable given the exigencies of an economic crisis and the state party's proffered reasons.

The foregoing analysis admittedly draws heavily from the dialogic practices of the Committee with states parties to the Covenant. We show in the following Part II that these practices similarly resonate with other institutions adjudicating questions of Covenant violations and the corresponding responsibility of states parties and non-state actors for such violations.

\section{Expanding Universes: Covenant Interpreters and Violations by State and non-State Actors}

\subsection{Covenant Interpreters}

International tribunals as well as domestic courts have directly applied and interpreted the Covenant, with some differences among them as to the scope of the questions they accept to adjudicate. ${ }^{115}$ In this sense, these institutions approach justiciability also from a functional standpoint, where the institution self-reflexively examines the parameters of its interpretive and/or adjudicative competence in relation to the subject-matter of the alleged Covenant violation. National, regional, and international courts have long been litigating economic, social, and cultural rights in parallel with the Committee's development of concepts of the 'minimum core' of these rights, principles of non-discrimination, reasonableness, proportionality, and non-retrogression. ${ }^{116}$ While there is no hard and fast hierarchy among international tribunals, agencies, and domestic courts interpreting the Covenant, one could nevertheless expect to find instances of 'cross-judging' ${ }^{117}$ among them on similar issues of Covenant rights.

of Available Resources' under an Optional Protocol to the Covenant, UN Doc E/C.12/2007/1, 21 September 2007, paras 4-5.

${ }^{115}$ See D Marcus, 'The Normative Development of Socioeconomic Rights through Supranational Adjudication',(2006) 42 Stanford JIL 53, 88.

${ }^{116}$ International Commission of Jurists (ICJ), 'Courts and the Legal Enforcement of Economic, Social and Cultural Rights. Comparative Experiences of Justiciability' (Human Rights and Rule of Law Series, Working Paper No 2, 2008) 23-64, <http://www.refworld.org/docid/4a7840562.html> [accessed 1 January 2014].

${ }^{117}$ See R Teitel \& R Howse, 'Cross-Judging: Tribunalization in a Fragmented but Interconnected Global Order', (2008-2009) 41 NYUJILP 959, 990 ('international legal order will resemble the 
Certainly not all institutions interpreting the Covenant possess strictly judicial functions, even if their institutional practices ultimately involve some assessment of a state's potential or actual responsibility for Covenant violations. Among these institutions, it is the Committee that has proven demonstrably influential in the development and interpretation of the Covenant, short of having a strict adjudicative procedure at its disposal long before the passage of the Optional Protocol to the Covenant in May 2013. The Committee has been lauded for

us[ing] relatively scant financial and political resources to good effect, rapidly bringing the Covenant's monitoring processes up to current treaty body standards, advancing its own political fortunes, and gaining greater general acceptance for the justiciability of economic, social and cultural rights through careful attention to norm development. ${ }^{118}$

It is not a court stricto sensu, but rather acts as the monitoring body of the Covenant, wielding powers under Part IV of the Covenant, after the delegation of authority made to it by the Economic and Social Council. ${ }^{119}$ Composed of 18 independent experts meeting three times a year, the Committee conducts the periodic review of state reports required in Articles 16 and 17 of the Covenant. ${ }^{120}$ While the Committee's work in the state reportage process certainly engages its interpretive functions with respect to the Covenant, the Committee actively provides guidance on the interpretation and application of Covenant norms through its issuance of General Comments, which 'give further substance to the norms and provisions found in the Covenant...outlining the content, intent, and legal meaning of the subjects they address.'121

messy, porous, multiple-value, and constituency politics of democratic pluralism, which is nevertheless underpinned by a more absolutist baseline commitment to the preservation of the human').

${ }^{118}$ B Lyon, 'Discourse in Development: A Post-Colonial "Agenda” for the United Nations Committee on Economic, Social and Cultural Rights' (2002) 10 American University Journal of Gender, Social Policy and the Law 535, 543.

${ }^{119}$ Economic and Social Council Resolution 1985/17.

${ }^{120} \mathrm{~J}$ Mertus, The United Nations and Human Rights: a Guide for a New Era (2 ${ }^{\text {nd }}$ edn, 2009) 83.

${ }^{121}$ UN Office of the High Commissioner for Human Rights, Handbook for National Human Rights Institutions, above n 17, 6 . 
While the degree of interpretive and authoritative weight of the General Comments may be disputed, ${ }^{122}$ it is nonetheless significant that no state party to the Covenant has ever objected to the Committee's institutional practice of issuing General Comments, notwithstanding the occasional challenges to the scope and reach of some of these interpretations. ${ }^{123}$ Furthermore, the Committee has made ample use of its authority to issue Statements, which are intended to assist states parties in 'clarifying and confirming its position with respect to major international developments and issues bearing upon implementation of the Covenant. ${ }^{\prime 24}$ Under the new Optional Protocol to the Covenant, the Committee gained a further competence to issue Views, ${ }^{125}$ which are responses to individual communications, that could also be a potential source for further interpretive (as well as a form of pseudo-jurisprudential) guidance on the implementation of the Covenant.

Generally, courts and other tribunals are not required or compelled to defer to the Committee's interpretations of the Covenant, quite unlike common law doctrines of 'administrative deference' or 'primary jurisdiction" ${ }^{\text {'26 }}$ which accord primacy to the interpretations or rulings of an administrative agency based on the latter's specialized expertise. However, while we expect domestic courts to continue to look towards the parameters of their own institutional competences when resolving the justiciability of attempted domestic applications of Covenant norms, it is still difficult to assume and generalize that domestic courts would always and necessarily act under a sharp line of separation from the political branches' commitments and representations to the Committee in the state reportage process of the Covenant. ${ }^{127}$ While some domestic courts have opted

\footnotetext{
${ }^{122}$ For the argument that General Comments should be viewed as 'authoritative interpretative instruments that give rise to a normative consensus on the meaning and scope of particular human rights', see C Blake, 'Normative Instruments in International Human Rights Law: Locating the General Comment' (NYU Center for Human Rights and Global Justice Working Paper No 17/2008), <http://chrgj.org/wp-content/uploads/2012/07/blake.pdf> accessed 30 July 2013].

${ }^{123}$ U Khaliq \& R Churchill, 'The Protection of Economic and Social Rights: a Particular Challenge?, in H Keller \& G Ulfstein (eds), UN Human Rights Treaty bodies: Law and Legitimacy (2012) 199, 207.

${ }^{124} \mathrm{Ibid}, 208$.

${ }^{125}$ See Optional Protocol, Arts 8 and 9.

${ }^{126}$ See J W Hilliard, 'Tapping Agency Expertise: The Doctrine of Primary Jurisdiction’ (2008) 96 Illinois Bar Journal 256.

${ }^{127}$ As one scholar puts it, "[o]bstacles to the judicial application of international law within domestic legal systems, based on its "diplomatic" and "inter-state" nature, should in principle be dismissed today. International law is no longer a law governing only the principle "external" relations of states...it governs the lives of individuals within states, all the more so at a time when the right
} 
to deny the direct applicability of the Covenant as a source of independent rights susceptible to causes of action, ${ }^{128}$ on the other hand, courts in other jurisdictions have permitted direct actionability for certain Covenant rights. ${ }^{129}$ Notably, a 2004 survey by the International Law Association found that the output of human rights treaty bodies had generally 'become a relevant interpretative source for many national courts. ${ }^{130}$ On balance, we observe that while other institutions are not obligated to defer to the Committee's interpretations of the Covenant, ${ }^{131}$ as a practical matter the Committee's interpretations could foreseeably figure within the adjudicative and interpretive calculus of other institutions seised of disputes involving allegations of a state's violation of the Covenant. ${ }^{132}$

We do not assert that the Committee's evaluation of state responsibility is

of access to curt is increasingly seen as a basic human right....Questions of non-justiciability are properly limited to those in which the court declines to exercise jurisdiction because the question pertains to inter-state relations and has no judicial or objective standard to decide it.' C Focarelli, International Law as Social Construct: the Struggle for Global Justice (2012) 345.

${ }^{128}$ Courts in Osaka, Japan, Belgium and the Netherlands have denied direct applicability of particular Covenant norms in a few cases. See Y Iwasawa, 'International Human Rights Adjudication in Japan', in B Conforti \& F Francioni (eds), Enforcing International Human Rights in Domestic Courts (1997) 223, 249-250. Inconsistencies have been observed between representations made by Canadian political branches to the Committee (on the judicial enforceability of the Covenant in domestic courts) and the actual rulings of Canadian courts. See G Brodsky, 'The Subversion of Human Rights by Governments in Canada', in M Young, S B Boyd, G Brodsky \& S Day (eds), Poverty: Rights, Social Citizenship, and Legal Activism (2007) 355, 365.

${ }^{129}$ Courts in Colombia, Serbia, Kenya and the Netherlands, for example, have directly applied some Covenant norms. See E Daly, Dignity Rights: Courts, Constitutions, and the Worth of the Human Person (2012) 151-3; S Djajić, 'Serbia', in D Shelton (ed), International Law and Domestic Legal Systems: Incorporation, Transformation, and Persuasion (2011) 526, 536; C Ryngaert, 'The Role of Human Rights in the Dutch Legal Order', in R Arnold (ed), The Universalism of Human Rights (2012) 237, 241; A Nollkaemper, National Courts and the International Rule of Law (2011) 42.

${ }^{130} \mathrm{R}$ van Alebeek \& A Nollkaemper, 'The Legal Status of Decisions by Human Rights Treaty Bodies in National Law', in Keller \& Ulfstein, above n 123, 356, 357.

${ }^{131}$ See G Oberleitner, Global Human Rights Institutions: Between Remedy and Ritual (2007) 99 ('By deciding on complaints, the treaty bodies give concrete meaning to specific human rights norms in concrete circumstances and thereby build up a kind of "jurisprudence", which can guide governments, NGOs and inter-governmental organizations in interpreting and understanding the content and relevance of international human rights norms').

${ }^{132}$ States assume the burden to justify to the Committee any absence of legal remedies to enforce Covenant rights. See M Langford \& J A King, 'Committee on Economic, Social and Cultural Rights: Past, Present and Future', in M Langford (ed), Social Rights Jurisprudence: Emerging Trends in International and Comparative Law (2008) 477, 496. Domestic courts, for example, could contribute to the implementation of states' international responsibility for Covenant violations by giving effect to principles of cessation and reparation. See A Nollkaemper, 'Internationally Wrongful Acts in Domestic Courts' (2007) 101 AJIL 760. 
in any way a legal precondition to lodging inter-state claims involving Covenant violations to international adjudication. ${ }^{133}$ Rather, we are of the view that the strengthened capacity and interpretive competences of the Committee in the assessment of alleged Covenant violations in the Optional Protocol could, at the very least, be a significant incentive for the International Court of Justice to use its authority to call upon the Committee as a relevant expert under Article 50 of the Court's Statute. ${ }^{134}$ After all, it is a well-known phenomenon in its fact-finding practices throughout its jurisprudence that the Court has scarcely acted motu proprio to obtain information from specialized agencies of the United Nations, tending mostly to resolve evidentiary issues on the basis of the information submitted by the states parties to a contentious dispute. ${ }^{135}$ Should a Covenant violation be brought to the Court in the future, the complexity of the normative and evidentiary issues therein would be one occasion for the Committee to contribute useful expert opinion and information in a contentious proceeding.

Furthermore, the establishment of three new Committee procedures (e.g. an individual and/or group communications procedure, a fact-finding inquiry procedure that could be initiated proprio motu, and an inter-state communications procedure) through the entry into force of the Optional Protocol to the Covenant on 5 May 2013 critically affects the landscape of Covenant interpretation in two ways. First, we find that, as regards the collective operation of procedures under the Protocol and the state reportage system in the Covenant, the interpretive process has been usefully streamlined to coalesce around the Committee's assessment techniques and procedures for determining state responsibility for Covenant violations.

Second, we submit that while the Committee's role in interpreting the Covenant has been reinforced through the new procedures in the Protocol, the latter does not diminish the broader forensic role of the plural interpretive communities whose inter-subjective judgments and observations ultimately influence the evaluation of a state's compliance with Covenant obligations. We refer to 'interpretive communities' according to the two senses famously coined by Ian Johnstone with respect to treaty practice:

\footnotetext{
${ }^{133}$ Application of the International Convention on the Elimination of all Forms of Racial Discrimination (Georgia $v$ Russian Federation), Preliminary Objections, ICJ Reports 2011 p 70, 120-9.

${ }^{134}$ ICJ Statute, Art 50 ('The Court may, at any time, entrust any individual, body, bureau, commission or other organization that it may select, with the task of carrying out an enquiry or an expert opinion').

${ }^{135}$ S Rosenne, Essays on International Law and Practice (2007) 235-50 (on fact-finding at the International Court of Justice).
} 
the [narrow] community of interpreters directly responsible for the conclusion and implementation of a particular treaty, and a broader, international community consisting of all experts and officials engaged in the various professional activities associated with treaty practice. ${ }^{136}$

Insofar as the determination of state responsibility for Covenant violations is concerned, the narrow interpretive community would be comprised of the Committee, as well as international and domestic courts that directly interpret and implement the Covenant. The 'broader' interpretive community, on the other hand, spans an assemblage of experts, other UN specialized agencies, governmental and nongovernmental organizations from whom all relevant and necessary information can be obtained when assessing a state party's measures or conduct affecting compliance with its duty to respect, protect, and fulfill economic, social, and cultural rights in the Covenant. ${ }^{137}$

Third, we note that the new procedures available under the Optional Protocol could afford the Committee the distinct opportunity to fully clarify and explicate the operational parameters of what it holds to be the actual extraterritorial scope of states parties' Covenant obligations. ${ }^{138}$ A case of first impression, such as the complex question of whether a state party has the duty to control the conduct of transnational corporations and ensure that the latter does not cause that state party to breach its Covenant obligations, ${ }^{139}$ could be one example of an interpretive issue that could be cautiously brought for

\footnotetext{
${ }^{136}$ I Johnstone, 'Treaty Interpretation: The Authority of Interpretive Communities' (1990-1991) 12 Mich JIL. 371, 385.

${ }^{137}$ See CECSR, Report on the Forty-Fourth and Forty-Fifth Sessions, UN Docs E/2011/22 \& E/C.12/2010/3, 3 May 2011, para 44 ('On various occasions in the past, the Committee has received information, mainly from non-governmental organizations, after consideration of the State party's report and adoption of concluding observations thereon. In fact this was follow-up information on the Committee's conclusions and recommendations. Not being in a position to consider and act upon such information without reopening its dialogue with a State party (except in cases specifically addressed in concluding observations), the Committee will consider and act upon the information received from sources other than a State party only in cases where such information has been specifically requested in its concluding observations').

${ }^{138}$ See F Coomans, 'The Extraterritorial Scope of the International Covenant on Economic, Social, and Cultural Rights in the Work of the United Nations Committee on Economic, Social and Cultural Rights', (2011) 11(1) HRLR 1.

${ }^{139}$ Academic literature on the Covenant remains tentative and under-theorised on the subject of state parties' duties as members of international financial institutions that issue decisions with development consequences for other states, as well as for state parties' duties as 'home states' of transnational corporations whose conduct may injure economic, social, or cultural
} 
Committee clarification and early dialogue between states Parties under the Protocol's inter-state procedure, without ripening into a full-blown contentious case leading to a direct finding of international responsibility (and the corollary reparations consequences), to which states might be more loathe to give consent.

Finally, while we recognize the proliferation of Covenant interpreters beyond the Committee to other national, regional, and international courts and tribunals, UN specialized agencies and other treaty bodies (and each with their respective evidentiary procedures and jurisdictional competences), we submit that the consolidation of information with the Committee would assist in substantiating and verifying future claims of international responsibility arising from Covenant violations. The bedrock of information now open to the Committee from the new Protocol procedures as well as the periodic reports submitted by states parties to the Covenant, together create a most authoritative and comprehensive aggregate index of states' subsequent practices in the interpretation and application of the Covenant. ${ }^{140}$ Localizing this wealth of information with the Committee through the Covenant reporting process and the Protocol procedures, carries, in our view, great potential for better harmonization of the Covenant's interpretive process, as well as clearer coordination and cross-referencing between the narrow and broad interpretive communities on economic, social, and cultural rights. The breadth of information now available through nearly five decades of the Committee's reporting process, the Committee's new proprio motu fact-finding mandate under the Optional Protocol to the Covenant, as well as the Committee's long-standing policy of openness to information from other experts, specialized agencies and non-governmental organizations certainly ensures, at the very least, that other Covenant interpreters could design appropriate forms of reparation or mechanisms for remedying violations of Covenant rights, ${ }^{141}$ in keeping with the

rights in other jurisdictions. For an interesting set of recent proposals, however, see $S$ Narula, 'International Financial Institutions, Transnational Corporations and Duties of States', in Langford, Vandenhole, Scheinin, \& Van Genugten, above n 38, 114-152 (arguing that international financial institutions (IFIs) and transnational corporations (TNCs) can be held indirectly accountable for Covenant violations in three ways - by requiring member states in IFIs to take the Covenant into account when participating in IFI decision-making processes; applying a 'decisive influence' and 'due diligence' standard to the relationship between the home state and the TNC as would make the home State accountable for TNC violations of the Covenant; and by requiring the home States of TNCs to enact domestic legislation applying the Covenant with extraterritorial reach).

${ }^{140}$ VCLT, Art 31(3)(b).

${ }^{141}$ See D Otto, 'Addressing Homelessness: Does Australia's Indirect Implementation of Human Rights Comply with its International Obligations?', in T Campbell, J Goldsworthy, \& A Stone 
fundamental obligation in Article 2(1) of the Covenant to realize all Covenant rights by 'all appropriate means'.

\subsection{State and Non-State Violators of the Covenant}

States and non-state actors alike could violate the Covenant. ${ }^{142}$ In order to 'respect' Covenant rights, States have to

guarantee conformity of their laws and policies regarding corporate activities...ensure that companies demonstrate due diligence to make certain that they do not impede the enjoyment of Covenant rights by those who depend on or are negatively affected by their activities. ${ }^{143}$

States 'protect' Covenant rights in relation to the conduct of corporate actors when they establish 'appropriate laws, regulations, as well as monitoring, investigation and accountability procedures to set and enforce standards for the performance of corporations. ${ }^{\text {, }}{ }^{14}$ States fulfill Covenant rights with the corporate sector when the latter's support is enlisted towards the progressive realization of Covenant rights, including encouraging corporations to 'assist, as appropriate, including in situations of armed conflict and natural disaster, host states in building capacities needed to address the corporate responsibility for the observance of economic, social and cultural rights.'145 Even as members of international organizations, states parties to the Covenant are expected to ensure that their actions remain consistent with respecting, protecting, and fulfilling Covenant rights. ${ }^{146}$ More direct obligations to promote universal respect for and observance of human rights may likewise apply to specialized agencies of

(eds), Protecting Human Rights: Instruments and Institutions (2003) 281, 288. Remedies for Covenant violations need not necessarily require judicial remedies when administrative remedies are adequate, 'accessible, affordable, timely and effective.' CESCR, General Comment No 9, above n 39, para 9.

${ }^{142}$ See CESCR, Statement on the Obligations of States Parties Regarding the Corporate Sector and Economic, Social and Cultural Rights, UN Doc E/C.12/2011/1, 20 May 2011 (Statement Regarding the Corporate Sector).

${ }^{143}$ Ibid, para 4. See also R McCorquodale, 'International Organisations and International Human Rights Law: One Giant Leap for Humankind', in K H Kaikobad and M Bohlander (eds), International Law and Power: Perspectives on Legal Order and Justice, Essays in Honour of Colin Warbrick (2009) 141, 183.

${ }^{144}$ CESCR, Statement Regarding the Corporate Sector, above n 142, para 5.

${ }^{145}$ Ibid, para 6.

${ }^{146}$ See CESCR, General Comment No 15, above n 39, para 36; UN High Commissioner for Human Rights, Liberalization of Trade in Services and Human Rights, UN Doc. E/C.4/Sub.2/2002/9, 25 June 2002, para 5. 
the United Nations, ${ }^{147}$ as well as potentially international organizations (such as international financial institutions) ${ }^{148}$ who are also 'subjects of international law and, as such, are bound by any obligations incumbent upon them under general rules of international law, under their constitutions or under international agreements to which they are parties.' ${ }^{, 19}$ International organizations, after all, can also be held responsible for committing internationally wrongful acts or omissions. ${ }^{150}$

In evaluating international responsibility for breach of any of the specific individual rights in the Covenant - such as those under Articles 6 (the right to work), 7 (the right to enjoyment of just and favourable conditions of work), 8 (the right to form and join trade unions), 9 (the right to social security), 10 (family rights), 11 (the right to adequate standard of living such as food, clothing, housing, and continuous improvement of living conditions), 12 (the right to enjoy the highest attainable standard of physical and mental health), 13 (the right to education), and 15 (the right to take part in cultural life, enjoy benefits of scientific progress and its applications, the protection of moral and material interests resulting from scientific, literary, or artistic production) the joint or separate conduct of states as well as non-state actors could be comprehensively considered insofar as they affect the processes and transactions for the realization of these rights. ${ }^{151}$ Beyond these specific Covenant rights, however, states and non-state actors such as international organizations are also bound to give effect to the obligation of 'international assistance and cooperation' that applies to all Covenant rights. ${ }^{152}$ The operative obligation in the Covenant, Article 2, invokes not only the obligation to 'progressively ensure' rights, but

\footnotetext{
${ }^{147}$ See Charter of the United Nations, Arts 50 and 55 (UN Charter).

${ }^{148}$ See F Gianviti, 'Economic, Social and Cultural Human Rights and the International Monetary Fund', in P Alston (ed), Non-State Actors and Human Rights (2005) 113.

${ }^{149}$ Interpretation of the Agreement of 25 March 1951 between the WHO and Egypt, Advisory Opinion, ICJ Reports 1980 p 73, 89.

${ }^{150}$ See Draft Articles on the Responsibility of International Organizations, ILC Ybk 2011/II(2).

${ }^{151}$ See CESCR, Globalization and Economic, Social and Cultural Rights, $18^{\text {th }}$ session, 27 April-15 May 1998, para 5 ('the Committee wishes to emphasize that international organizations, as well as the governments that have created and manage them, have a strong and continuous responsibility to take whatever measures they can to assist governments to act in ways which are compatible with their human rights obligations and to seek to devise policies and programmes which promote respect for those rights. It is particularly important to emphasize that the realms of trade, finance and investment are in no way exempt from these general principles and that the international organizations with specific responsibilities in those areas should play a positive and constructive role in relation to human rights').

${ }^{152}$ Covenant, Arts 2(1), 11 and 12.
} 
does not do so without first requiring that states take these steps individually and through international assistance and co-operation, especially economic and technical. ${ }^{\prime 53}$ No comparable reference to international engagement exists, for example, in the ICCPR, which restricts obligations by focusing in great detail on the rights of individuals in the jurisdiction of a state party. ${ }^{154}$ Rather, the Covenant contemplates states that actively engage in respecting, protecting, and fulfilling Covenant rights both domestically and in their actions as members of the international community. ${ }^{155}$ For those states pursuing technical or economic assistance in conjunction with another state party to the Covenant there is also a question, to our knowledge under-theorized at this point, ${ }^{156}$ as to the precise nature of the obligation of a state that is in a position to provide such assistance. ${ }^{157}$ In a progressive reading of its new mandate under the Optional Protocol to the Covenant, one can therefore expect the Committee to assert its motu proprio fact-finding competence to seek relevant information, ${ }^{158}$ such as actions taken by a state party to fulfill its obligations of cooperation.

\footnotetext{
${ }^{153}$ Covenant, Art 2(1).

${ }^{154}$ ICCPR, Art 2(1).

${ }^{155}$ On states parties' control of extraterritorial conduct by private actors in relation to the states' duties to provide access, not to impede access or not to tolerate private actors' conduct that impedes access, see CESCR, General Comment No 15, above n 39, paras 23-4; CESCR, General Comment No 18, above n 39, para 25; CESCR, General Comment No 19, above n 39, paras 45 and 54.

${ }^{156}$ We note that General Comment No 2 (on international technical assistance matters) bypasses this question altogether: CESCR, General Comment No 2, above n 39.

${ }^{157}$ Although we note the Committee's recently increasing practice of issuing statements on topical applications of the Covenant in states' economic policy-making, see CESCR, Statement regarding the corporate sector, above $\mathrm{n} 142$ (holding, among others, that ' $\mathrm{r}$ ] especting rights requires States Parties to guarantee conformity of their laws and policies regarding corporate activities with economic, social and cultural rights set forth in the Covenant...States Parties shall ensure that companies demonstrate due diligence to make certain they do not impede the enjoyment of Covenant rights by those who depend on or are negatively affected by their activities' (para 4); 'Protecting rights means that States Parties effectively safeguard rights holders against infringements of their economic, social and cultural rights involving corporate actors, by establishing appropriate laws, regulations, as well as monitoring, investigation, and accountability procedures to set and enforce standards for the performance of corporations' (para 5); 'Fulfilling rights entails that States Parties undertake to obtain the corporate sector's support to the realization of economic, social and cultural rights' (para 6)); letter of the Chairperson of the Committee on Economic, Social and Cultural Rights in relation to the protection of Covenant rights in the context of economic and financial crisis (Office of the High Commissioner for Human Rights, Open letter from the Chairperson of the Committee on Economic, Social and Cultural Rights, 16 May 2012, <http://www2.ohchr.org/english/bodies/cescr/docs/LetterCESCRtoSP16.05.12.pdf> [accessed May 2014].

${ }^{158}$ See Optional Protocol, Art 11.
} 
In sum, we submit that the plurality of Covenant interpreters did not create utterly dissonant interpretations or methods of determining international responsibility for Covenant violations. Rather, precisely because state and nonstate compliance with the programmatic, evolutive, ${ }^{159}$ and transactional nature of Covenant rights could only be fully and comprehensively determined by accessing broad bases of information over time, ${ }^{160}$ it is now inevitable that Covenant interpreters would refer to the Committee not just for the authoritative interpretation of the content of Covenant rights (as set forth in its General Comments, statements, and other views), but also for the comprehensive evidentiary resources now made available from the state periodic reporting processes, as well as the new competences of the Committee under the Optional Protocol procedures. The modern paradigm for determining international responsibility for Covenant violations thus denotes a steady integration of information and interpretation, and not normative or institutional fragmentation.

\footnotetext{
${ }^{159} \mathrm{~K}$ D Beiter, The Protection of the Right to Education by International Law (2006) 232 ("[t]he travaux préparatoires of the ICESCR show that the drafters of the Covenant intended that its rights provisions should be framed in rather general terms and that it should be the task of the Specialised Agencies to transform these into detailed rules'). As defined by the International Court of Justice, 'evolutive interpretation' applies to treaties containing terms intended by treaty parties to evolve and allow for future developments in international law as well as factual phenomena altering the meaning of a norm. Dispute regarding Navigational and Related Rights (Costa Rica v Nicaragua), ICJ Reports 2009 p 213, 242-3(see also in particular para 66 where the Court declared that 'where the parties have used generic terms in a treaty, the parties necessarily having been aware that the meaning of the terms was likely to evolve over time, and where the treaty has been entered into for a very long period or is "of continuing duration", the parties must be presumed, as a general rule, to have intended those terms to have an evolving meaning').

${ }^{160}$ In the practice of the European Court of Human Rights, the principle of evolutive interpretation 'allows for variations in time' or 'that the meaning of a concept can change over time.... kind of autonomous interpretation in its broad, organic sense, because it imposes a uniform interpretation of contested concepts'. E Brems, Human Rights: Universality and Diversity (2001) 396. The ICESCR is a prime candidate for the technique of evolutive interpretation, precisely because its normative content is indeed expected to change over time. Rights to 'the highest attainable standard of health', an 'adequate standard of living,' 'social security', 'education', among others, manifestly contemplate that interpreters of the Covenant assume an ongoing project of contextual assessment.
} 


\section{Conclusion: Reframing State Responsibility for Covenant Violations}

Covenant interpreters seeking to determine international responsibility for violations of the Covenant inimitably engage the dynamism of norms and facts. As we discussed in Part I, such dynamism need not (and should not) be equated with a situation of complete normative indeterminacy, since treaty interpreters could well locate the applicable criteria in their assessment, first tracing a state party's compliance with the Covenant beginning with the 'normative lattice' of minimum core obligations, the principle of non-discrimination, and the principle of non-retrogression all collectively operating as the minimum social protection baseline for a state party to the Covenant; then expanding the analysis outwards with respect to the state party's 'progressive realization' of Covenant rights. Neither should, as we showed in Part II, factual or informational dynamism breed license for the Covenant's interpretive communities to engage in hopelessly Protean (and ultimately arbitrary) exercises in inter-subjective judging. The de facto reference to the Committee's interpretive guidance by other tribunals suggests to us that, with the entry into force of the Protocol and the expansion of the Committee's interpretive competences, there is even greater potential for outcome-determinative coordination between institutions tasked with Covenant interpretation. The expansion of the Committee's mandate to include institutional oversight and soft quasi-adjudicative interpretation within the Protocol's cooperative framework of inter-state and individual communications procedures, administratively complements the well-settled reportage and information-gathering functions under the Covenant's periodic reporting system in operation for nearly five decades since the entry into force of the Covenant.

The assessment of internal responsibility for Covenant violations is, at its core, a discursive process ${ }^{161}$ containing an internal logic shared by its plural interpretive communities. There is less of the spectral fear of 'judicial activism'162 where evolutive interpretation is adopted for Covenant rights, because the broad bases of information inevitably associated with these rights enables a conceivable transparent and continuing dialectic between narrow interpretive

\footnotetext{
${ }^{161}$ We subscribe to Jurgen Habermas' conception of the discourse theory of law proceeding from the question of 'how constitutional rights and principles must be conceived and implemented if in the given context they are to fulfill the functions normatively ascribed to them.' See J Habermas, Between Facts and Norms: Contributions to a Discourse Theory of Law and Democracy (1998) 194.

${ }^{162}$ See P Dupuy, 'Evolutionary Interpretation of Treaties: Between Memory and Prophecy', in E Canizzaro (ed), The Law of Treaties Beyond the Vienna Convention (2011) ch 7.
} 
communities (international courts, domestic courts, or the Committee) and the broader interpretive communities (groups, individuals, governmental or nongovernmental organizations, third states) that are themselves interested in the enforcement of economic, social and cultural rights. This continuing dialectic is precisely what makes the new collective index of subsequent practices available from both the Covenant reporting system and the Protocol's innovative procedures more reliable for future assessments of international responsibility for Covenant violations. ${ }^{163}$

The modern integrated paradigm for determining international responsibility arising from Covenant violations owes its emergence from nearly five decades of dialectical achievements since the Covenant entered into force. The Committee's General Comments helped fulfill a quasi-legislative purpose originally envisaged in the Covenant's travaux préparatoires, where 'the drafters of the Covenant intended that its rights provisions should be framed in rather general terms and that it should be the task of the Specialised Agencies to transform these into detailed rules. ${ }^{, 164}$ The widespread adjudication of economic, social and cultural rights by various national, regional, and international courts and tribunals, in turn, contributed to the content and normative development of dynamic norms, rights, and obligations in the Covenant. ${ }^{165}$ Decades of participation by states, international organizations, other UN specialized agencies and other non-state actors in the Committee's reportage procedures under the Covenant have also helped pave the way for the recent adoption of uniform empirical methodologies for determining state and non-state compliance with the Covenant. ${ }^{166}$ All of these incidents, in our view, pull our assessment of international responsibility for Covenant violations towards a path of integrated interpretation and evidentiary substantiation.

\footnotetext{
${ }^{163} \mathrm{~A}$ Müller, The Relationship between Economic, Social and Cultural Rights and International Humanitarian Law (2013) 30-1 ('taking account of subsequent developments in relation to the treaty such as subsequent practice and subsequent agreements that relate to the treaty - has a firm standing in the interpretation of international human rights law as it allows for a "dynamic" or "evolutive" interpretation of the law in the context of "present day conditions". Many aspects of the content of human rights norms have become clear only after the relevant treaties have been adopted, especially through the (interpretative) work of UN treaty bodies and regional human rights courts/commissions').

${ }^{164}$ Beiter, above n 159, 232.

${ }^{165}$ International Commission of Jurists (ICJ), 'Courts and the Legal Enforcement of Economic, Social and Cultural Rights. Comparative Experiences of Justiciability' (Human Rights and Rule of Law Series No 2, 2008), 23-64, <http://www.refworld.org/docid/4a7840562.html> [accessed 1 January 2014].

${ }^{166}$ Ibid; also above nn 73-4.
} 
Admittedly, the process of ascertaining state responsibility for Covenant violations introduces a further temporal dimension that could conceivably strain the treaty interpreter's legal and factual imagination. A Covenant violation is not an easy conclusion to draw, given the broad, manifold, and somewhat porous ways for states to 'respect', 'protect', and 'fulfill' Covenant rights, coupled with the continuing normative task of the treaty interpreter to observe due regard for the particularities of a state's capacities, capabilities, conditions, and contexts at the time of the assessment of the alleged Covenant violation. This is where both the forensic contributions from broader interpretive communities, as well as the 'cross-judging' influences of narrow interpretive communities, could ameliorate the difficulties in the process of evaluating whether a state party to the Covenant or a non-state actor incurs international responsibility. Reframing our analysis of state responsibility for Covenant violations is thus a signal opportunity for those of us within either narrow and/or broad interpretive communities to revolutionize the logics of engagement between our internal and external discourses on economic, social, and cultural rights. 